\author{
UNITED STATES \\ DEPARTMENT OF THE INTERIOR \\ U.S. GEOLOGICAL SURVEY
}

\title{
WATER-RESOURCES ACTIVITIES IN UTAH \\ BY THE U.S. GEOLOGICAL SURVEY, \\ OCTOBER 1, 1989, TO SEPTEMBER 30, 1990
}

Compiled by Joseph S. Gates and Stefanie L. Dragos

U.S. GEOLOGICAL SURVEY

Open-File Report 91-495

Salt Lake City, Utah 


\section{U.S. DEPARTMENT OF THE INTERIOR \\ MANUEL LUJAN, JR., Secretary \\ U.S. GEOLOGICAL SURVEY \\ Dallas L. Peck, Director}

For additional information write to:

\section{District Chief}

U.S. Geological Survey Water Resources Division

Room 1016 Administration Building 1745 West 1700 South

Salt Lake City, Utah 84104
Copies of this report can be purchased from:

U.S. Geological Survey

Books and Open-File Reports Section Federal Center

Box 25425

Denver, Colorado 80225 


\section{CONTENTS}

\section{INTRODUCTION}

Basic mission and program of the Water Resources Division,

U.S. Geological Survey. ....................................................................................... 1

Utah District organization........................................................................................ 2

Program funding and cooperating agencies.......................................................... 4

Reports released or published ..................................................................................... 5

CURRENT PROJECTS BY NUMBER AND TITLE............................................ 7

Collection Of Hydrologic Data.................................................................................. 7

001 Surface-water data, including seepage losses from canals ..................... 7

002 Ground-water data and ground water conditions in Utah ..................... 10

003 and 004 Water-quality and fluvial sediment data .................................. 13

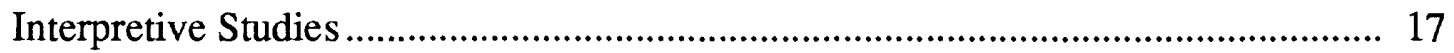

007 Statewide water use ........................................................................ 17

177 Model for predicting the water and salt balance of Great Salt Lake for selected water levels...................................................................... 19

180 Hydrology of the central Sevier Valley, Central Utah, with emphasis on the Sevier-Sigurd Basin ............................................... 20

182 Plan to determine effects of injecting brine, Uinta Basin ........................ 21

187 Ground-water contamination at Hill Air Force Base,

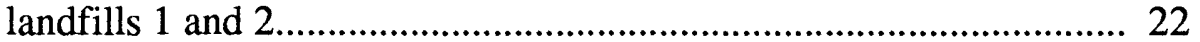

188 Ground-water hydrology of Sanpete Valley and the San Pitch River drainage basin, Utah................................................................ 23

190 Ground-water hydrology of the upper Sevier River basin, south-central Utah, and simulation of the ground-water system in Panguitch Valley

191 Detailed assessment of effects of irrigation drainage on water quality in the middle Green River basin, Utah

193 Hydrology and water availability in southeastern Tooele Valley, northeastern Rush Valley, and adjacent areas in the Oquirrh Mountains, Tooele County, Utah 


\section{CURRENT PROJECTS BY NUMBER AND TITLE --Continued}

Interpretive Studies--Continued

194 Hydrology of Heber and Round Valleys, Wasatch County, Utah, with emphasis on ground water

196 Ground water in southern Utah and Goshen Valleys, Utah County ...... 31

197 Hydrologic response to land subsidence caused by underground coal mining, Carbon County, central Utah

198 Investigation of salinity of water in the Navajo Sandstone aquifer in the Aneth area, San Juan County, Utah

199 Definition of recharge areas, aquifers, and confining beds, and classification of aquifers based on water quality in the East Shore area of Great Salt Lake; Box Elder, Weber, and Davis Counties, Utah 35

200 Definition of recharge areas, aquifers, and confining beds, and classification of aquifers in terms of water quality-Wasatch Front, Cache Valley, and lower Bear River Valley in Cache, Box Elder, Salt Lake, and Utah Counties, Utah

202 Innovative techniques of mapping attributes in support of wellhead protection area delineation, Salt Lake County, Utah.

203 Ground water and ground-water/surface-water relations in Cache Valley, Cache County, Utah, and adjacent parts of Idaho.

204 Identification and quantification of mechanisms causing decreasing salt-crust thickness, Bonneville Salt Flats, western Utah 42

205 Ground-water flow and solute migration in the Salt Lake Valley, Utah. 44

206 Definition of recharge areas, physical extent, and water quality in the principal aquifers in western Kane County, Utah

207 Determination of channel-migration processes, San Juan River near Bluff, Utah 


\section{ILLUSTRATIONS}

Figures 1-6. Maps of Utah showing:

1. Location of U.S. Geological Survey, Water Resources Division, offices and general areas of responsibility ......................................... 3

2. Location of gaging stations........................................................................ 9

3. Location of observation wells where ground-water levels were

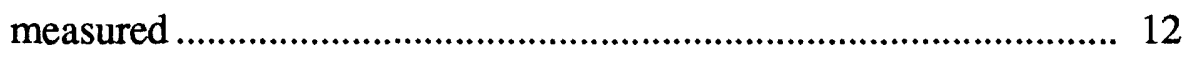

4. Location of surface-water-quality stations ............................................ 15

5. Location of observation wells where water samples were collected for monitoring ground-water quality ................................................ 16

6. Location of interpretive studies ............................................................ 18 


\title{
WATER-RESOURCES ACTIVITIES IN UTAH \\ BY THE U.S. GEOLOGICAL SURVEY, OCTOBER 1, 1989, TO SEPTEMBER 30, 1990
}

\author{
Compiled by Joseph S. Gates and Stefanie L. Dragos
}

\section{INTRODUCTION}

This report contains summaries of the progress of water-resources studies in Utah by the U.S. Geological Survey, Water Resources Division, Utah District, from October 1, 1989, to September 30, 1990. The program in Utah during this period consisted of 25 projects; a discussion of each project is given in the body of the report.

The following sections outline the basic mission and program of the Water Resources Division, the organizational structure of the Utah District, the distribution of District funding in terms of source of funds and type of activity funded, and the agencies with which the District cooperates. The last part of the introduction is a list of reports produced by the District from October 1989 to September 1990.

\section{Basic Mission and Program of the Water Resources Division,}

\section{U.S. Geological Survey}

The mission of the Water Resources Division, which supports the overall mission of the U.S. Department of the Interior and the Geological Survey, is to provide the hydrologic informatin and understanding needed for the best use and management of the Nation's water resources for the benefit of the people of the United States.

The mission of the Division is accomplished through programs supported by the U.S. Geological Survey independent of, or in cooperation with, other Federal and non-Federal agencies. These programs involve:

1. Collecting, on a systematic basis, data needed for the continuing determination and evaluation of the quantity, quality, and use of the Nation's water resources.

2. Conducting analytical and interpretive water-resource appraisals of the occurrence, availability, and the physical, chemical, and biological characteristics of surface and ground water.

3. Conducting basic problem-oriented research in hydrology to improve the scientific basis for investigations and measurement techniques, and to predict quantitatively the response of hydrologic systems to stress.

4. Disseminating water data and the results of investigations and research through reports, maps, computerized information services, and other forms of public releases.

5. Coordinating the activities of Federal agencies in the acquisition of water data for streams, lakes, reservoirs, estuaries, and ground water.

6. Providing scientific and technical assistance in hydrology to other Federal, State, and local agencies; to licensees of the Federal Power Commission; and to international agencies on behalf of the Department of State. 
7. Administering the provisions of the Water Resources Research Act of 1984, which includes the State Water Resources Research Institute Program (Section 104) and the National Water Resources Research Grant Program (Section 105).

8. Acquiring information useful in predicting and delineating water-related natural hazards from flooding, volcanoes, mudflows, and land subsidence.

\section{$\underline{\text { Utah District Organization }}$}

The Utah District of the Water Resources Division is organized into five sections under the District Chief (see organization chart). Water-resources projects are conducted by the Investigations Section (primarily interpretive studies) and Hydrologic-Surveillance Section (primarily collection of hydrologic data). Responsibility for each project is assigned to a project chief. Support for project work is supplied by the Publications Section, which processes and illustrates reports, and the Computer Services and Administrative Services Sections. The Utah District consists of the District Office in Salt Lake City, a Subdistrict Office in Cedar City, and Field Headquarters in Salt Lake City and Moab. The location of these offices and their areas of responsibility are shown in figure 1.

\section{Utah District Organization}

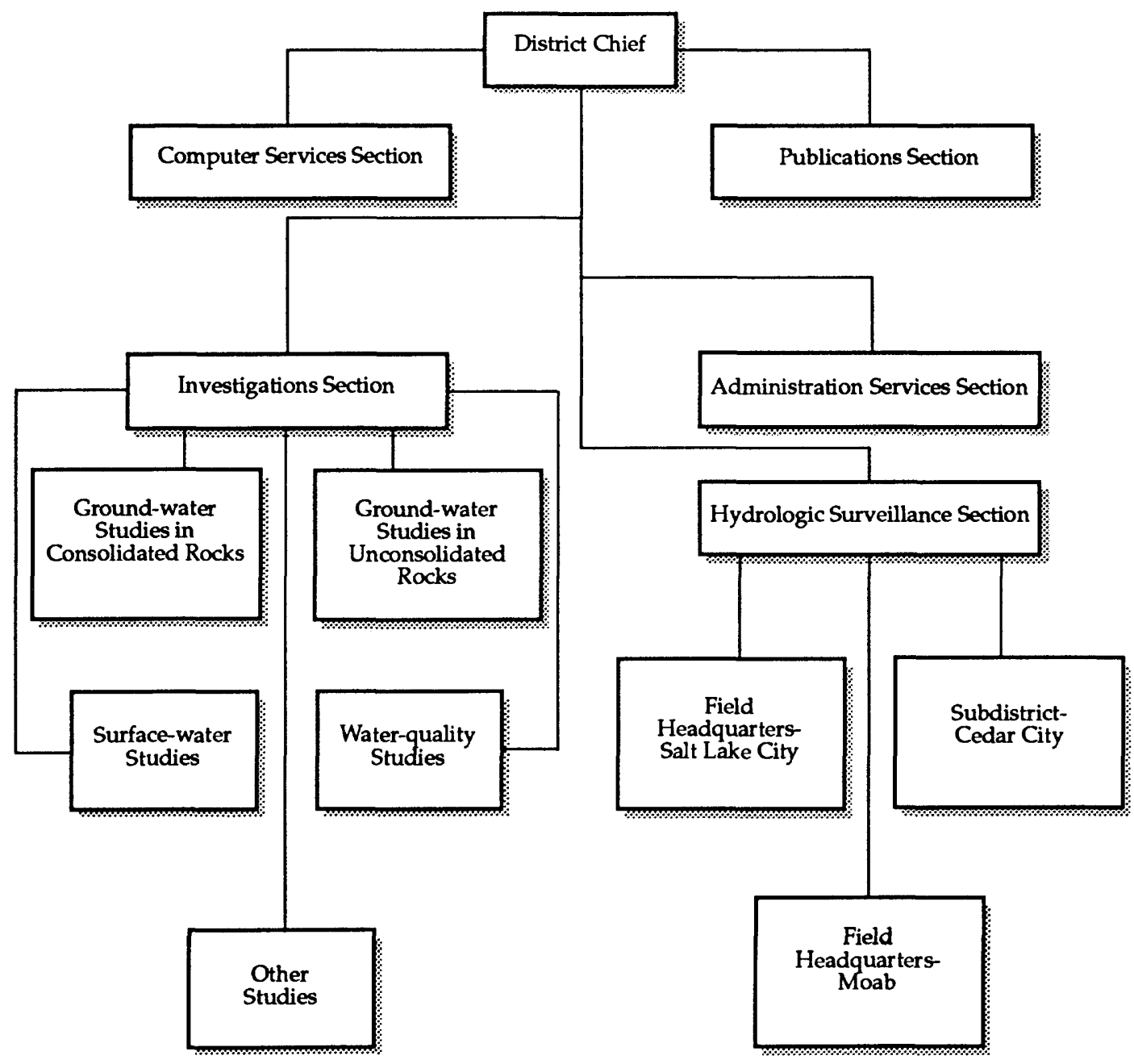




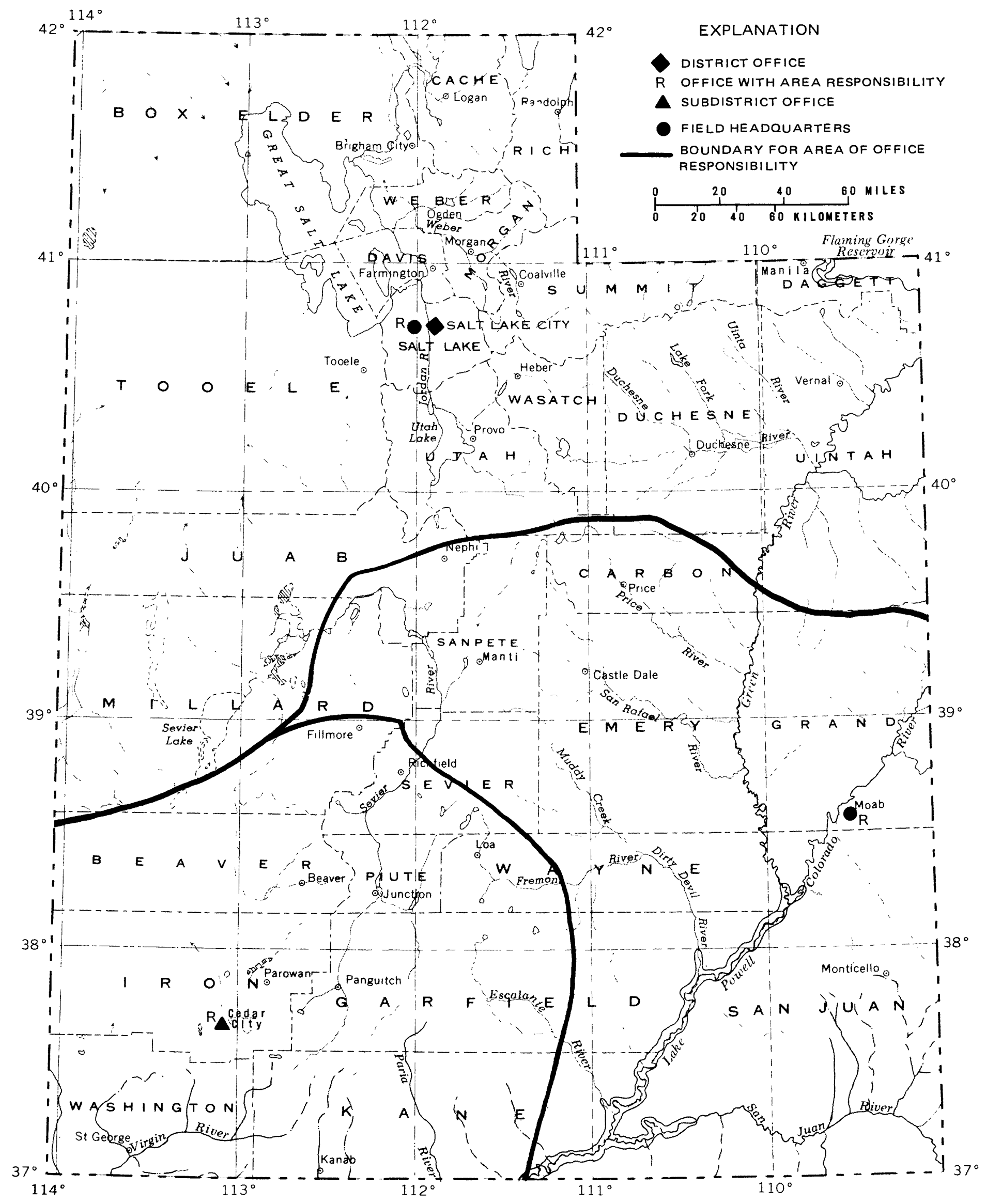

Figure 1.--Location of U.S. Geological Survey, Water Resources Division, offices and general areas of responsibility. 


\section{Program Funding and Cooperating Agencies}

Funds to support water-resources work by the Utah District are from three sources. Cooperative-Program funds and services are provided from State and local government agencies and generally are matched by Federal funds on a 50-50 basis. Funds transferred from other Federal agencies (OFA) are part of the OFA Program, and funds appropriated directly to the Geological Survey by the Congress are part of the Federal Program. In fiscal year 1990, the total financial support from these programs for the Utah District was about $\$ 4.1$ million. The distribution of funds among the three sources is shown below:

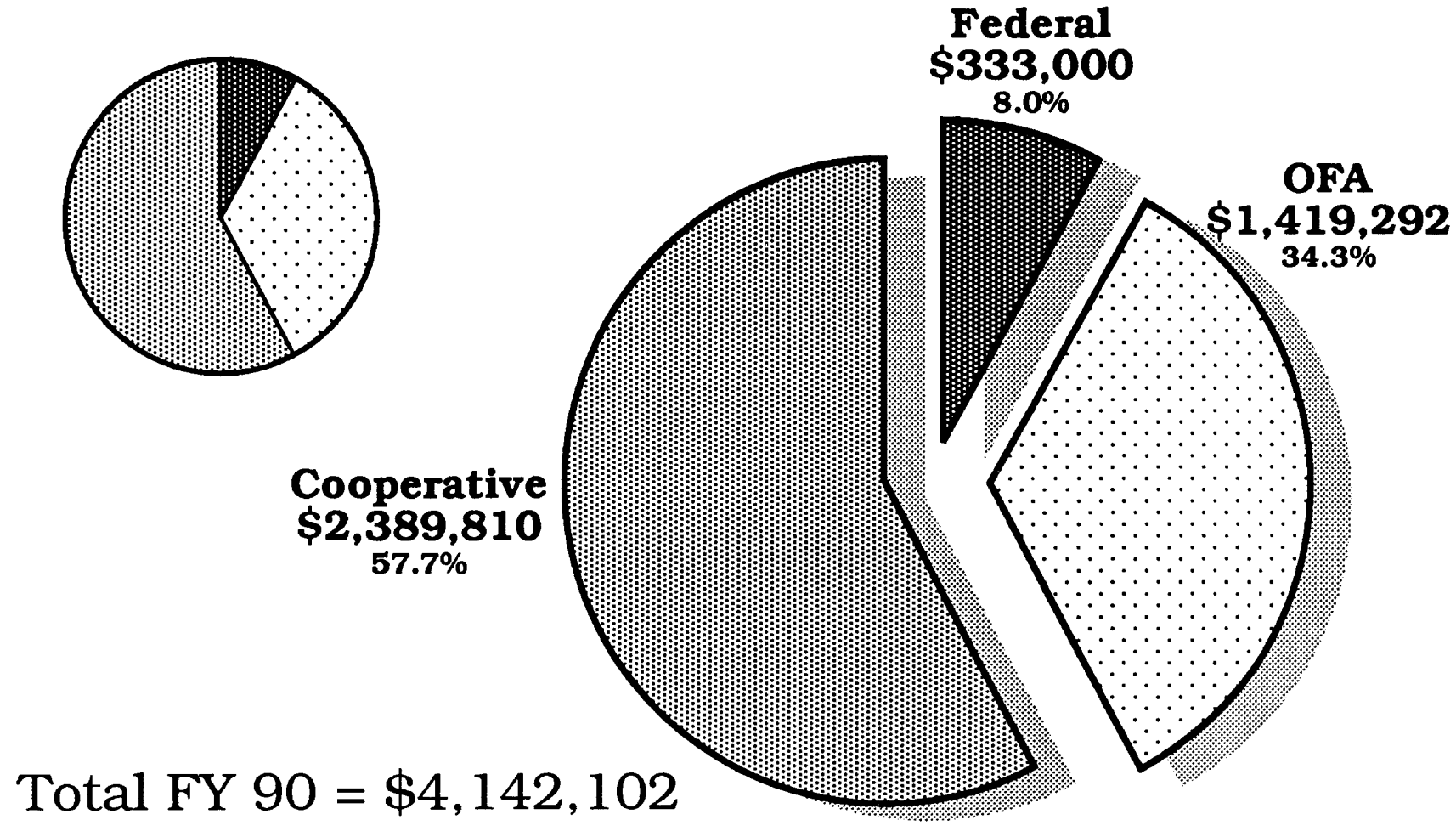

In fiscal year 1990, the Utah District pursued two broad categories of projects: (1) hydrologic data collection, and (2) interpretive studies and areal appraisals. Approximately 49 percent of the program was hydrologic-data collection and 51 percent interpretive studies and appraisals. These studies provide water managers and planners with information about the availability and quality of Utah's water resources.

From October 1, 1989, to September 30, 1990, the State and local cooperating agencies for District projects were:

Utah Department of Natural Resources

Division of Water Rights

Division of Water Resources

Division of Oil, Gas, and Mining

Geological and Mineral Survey 
Utah Department of Health, Division of Environmental Health

Bear River Commission

Salt Lake County Division of Flood Control and Water Quality

Central Utah Water Conservancy District

Utah Department of Agriculture

Utah Department of Transportation

Wasatch County

Weber Basin Water Conservancy District

Weber River Water Users Association

Wasatch County Water Users, Associated

Tooele County

City of Tooele

Ogden River Water Users Association

Utah Division of State Lands and Forestry

Kane County

City of Kanab

Kanab Area Water Association, Inc.

Five County Association of Governments

The Federal cooperating agencies were:

U.S. Bureau of Land Management

U.S. Bureau of Reclamation

U.S. Air Force

U.S. Soil Conservation Service

U.S. Environmental Protection Agency

U.S. Bureau of Indian Affairs

Office of the Secretary, U.S. Department of the Interior

Federal Power Commission (Utah Power and Light Co.)

\section{Reports Released or Published}

Reports prepared by or in cooperation with the Utah District can be obtained at the following locations:

Utah District Office: Open-File Reports; Water-Resources Investigations Reports; HydrologicData Reports; Water-Data Reports; and Utah Department of Natural Resources Technical Publications, Cooperative Investigations Reports, and Water Circulars.

U.S. Geological Survey Earth Science Information Center: (125 South State Street, Salt Lake City): U.S. Geological Survey Water-Supply Papers, Professional Papers, Circulars, and Hydrologic Investigations Atlases.

Utah Department of Natural Resources, Division of Water Rights: Technical Publications, Water Circulars, Hydrologic-Data Reports, Water-Use Reports.

Utah Department of Natural Resources, Division of Water Resources: Cooperative Investigations Reports. 
The following reports were published during October, 1989-October, 1990:

Arnow, Ted, and Stephens, D.W., 1990, Hydrologic characteristics of the Great Salt Lake, Utah: 1847-1986: U.S. Geological Survey Water Supply Paper 2332, p. 32.

Clark, D.W., Appel, C.L., Lambert, P.M., and Puryear, R.L., 1990, Ground-water resources and simulated effects of withdrawals in the East Shore area of Great Salt Lake, Utah: Utah Department of Natural Resources Technical Publication No. 93, 150 p.

Gates, J.S., Anderson, P.B., and Wold, S.R., 1990, Potential recharge areas and nonpoint sources of ground-water contamination, Salt Lake Valley and Wasatch Front, Utah, in Abstracts: Utah Nonpoint-Source Water Quality Conference, Park City, Utah, September 20-21, $1990,11 \mathrm{p}$.

Gates, J.S., Thompson, K.R., Baskin, R.L., Wold, S.R., and Anderson, P.B., 1990, Hydrogeologic factors related to the susceptibility to contamination of the principal aquifers of the Wasatch Front and adjacent areas, Utah, in Minimizing Risk to the Hydrologic Environment: American Institute of Hydrology, 1990 Spring meeting program, Las Vegas, Nevada, March 12-16, 1990, $31 \mathrm{p}$.

Herbert, L.R., and others, 1990, Ground-water conditions in Utah, spring of 1990: Utah Division of Water Resources Cooperative Investigations Report No. 30, 84 p.

Herbert, L.R., and Smith, G.J., 1989, Seepage study of the South Bend, Richfield, and Vermillion Canals, Sevier County, Utah: Utah Department of Natural Resources Technical Publication No. 97,50 p.

Price, Don, Stephens, D.W., and Conroy, L.S., 1989, Hydrologic evaluation and water-supply considerations for five Paiute Indian land parcels, Millard, Sevier, and Iron Counties, southwestern Utah: U.S. Geological Survey Water-Resources Investigations Report 89$4010,39 \mathrm{p}$.

Stephens, D.W., 1990, Changes in lake levels, salinity, and the biological community of Great Salt Lake, Utah, 1847-1987: Hydrobiologia, v. 197, p. 139-146.

Stephens, D.W., Waddell, Bruce, and Miller, J.B., 1989, Irrigation drainage: Green River Basin, Utah, in Planning now for irrigation and drainage: Proceedings, American Society of Civil Engineers, Lincoln, Nebraska, July 18-21, 1988.

Stephens, D.W., and Waddell, Bruce, 1989, Selenium contamination of water fowl areas in Utah and options for management, in Robarts, Richard, ed., Proceedings of the Conference on Aquatic Ecosystems in Semi-Arid Regions, Saskatchewan, Canada, August 1990. 


\title{
CURRENT PROJECTS BY NUMBER AND TITLE
}

\author{
Collection of Hydrologic Data
}

\author{
Surface-water Data, Including Seepage Losses \\ From Canals
}

Number: UT-00-001

Cooperating Agencies: U.S. Bureau of Reclamation; U.S. Bureau of Land Management; U.S. Soil Conservation Service; Utah Division of Water Rights; Utah Division of Water Resources; Utah Geological and Mineral Survey; Bear River Commission; Weber Basin Water Conservancy District; Salt Lake County Division of Flood Control and Water Quality; Weber River Water Users Association; Ogden River Water Users Association; Federal Power Commission (Utah Power and Light Co.)

Staff: L.R. Herbert, Hydrologic Technician, Project Chief (part time)

Other District personnel as assigned

Period of Project: Continuing

Objectives: To obtain data on stream discharge, reservoir contents, and lake stage at selected sites throughout Utah (fig. 2).

Approach: Use standard methods for the operation and maintenance of streamflow-gaging stations and for the computation, computer storage, and publication of the data.

Progress: Data collection and computation necessary for the publication of discharge records for 185 streamflow-gaging stations and contents and stage records for 19 reservoir and 4 lake-stage stations continued during the year. In addition, periodic measurements were made of flow of water through the breach in the causeway across Great Salt Lake. The location of the stations and station numbers are shown in figure 2. Data collected at these stations, as well as larger-scale maps showing station locations, are given in the series of reports "Water resources data for Utah", U.S. Geological Survey Water-Data Reports. The stations are classified as follows:

Number of stations

Discharge

Current use 127

Hydrologic data for planning and design $\quad 47$

Benchmark for long-term trends 11

Contents of reservoirs and lakes $\quad 21$

Stage of Great Salt Lake 2

Because of funding constraints, 14 gaging stations were discontinued. These stations were:

West Pond near Wendover, Utah

Courthouse Wash near Moab, Utah

North Fork Dry Fork near Dry Fork, Utah

Brownie Canyon Creek above Sinks near Dry Fork, Utah 
Dry Fork at Mouth near Dry Fork, Utah

Bitter Creek near Bonanza, Utah

Minnie Maud Creek near Myton, Utah

Beaver Creek near Soldier Summit, Utah

Willow Creek near Castle Gate, Utah

High Creek near Richmond, Utah

George Creek near Yost, Utah

Fort Pierce Wash near St. George, Utah

Oak Creek near Fairview, Utah

San Pitch River near Mount Pleasant, Utah

Gaging stations established were:

East Canyon Creek near Park City, Utah

Kimball Creek near Kimball Junction, Utah

Silver Creek near Wanship, Utah

Santa Clara River above Baker Reservoir, near Central, Utah

Bear River near Smithfield, Utah

West Fork Duchesne River below Vat Dam diversions, near Hanna, Utah

West Fork Duchesne River above North Fork, near Hanna, Utah

Seepage studies:

A report on the seepage study of Timpanogos, Wasatch, Sagebrush, and Spring Creeks, and Upper Charleston and Lower Charleston Canals, Wasatch County, was prepared.

West Desert pumping project:

Monitoring of the stage of the West Pond, West Desert pumping project, continued.

Plans for Next Year: Continue operation of network. Prepare 1990 water-year records for publication. Plan a seepage study on the Bear River in Cache Valley, make flow measurements, and complete report. Complete report on floods in the Great Basin during 1983-84, and on the flood resulting from the Quail Creek Reservoir dike failure. Continue monitoring flow through the breach in the Great Salt Lake causeway. Complete report on flash flood near Lake Powell. Complete report on surface-water reconnaissance of the Sevier River Basin above Sevier Bridge Reservoir.

\section{Reports:}

ReMillard, M.D., and others, 1990, Water-resources data for Utah, water year 1989: U.S.Geological Survey Water-Data Report UT-89-1.

U.S. Geological Survey, 1990, National Water Summary 1987-88-Floods and Droughts: U.S. Geological Survey Water-Supply Paper 2350, p. 491-498. 


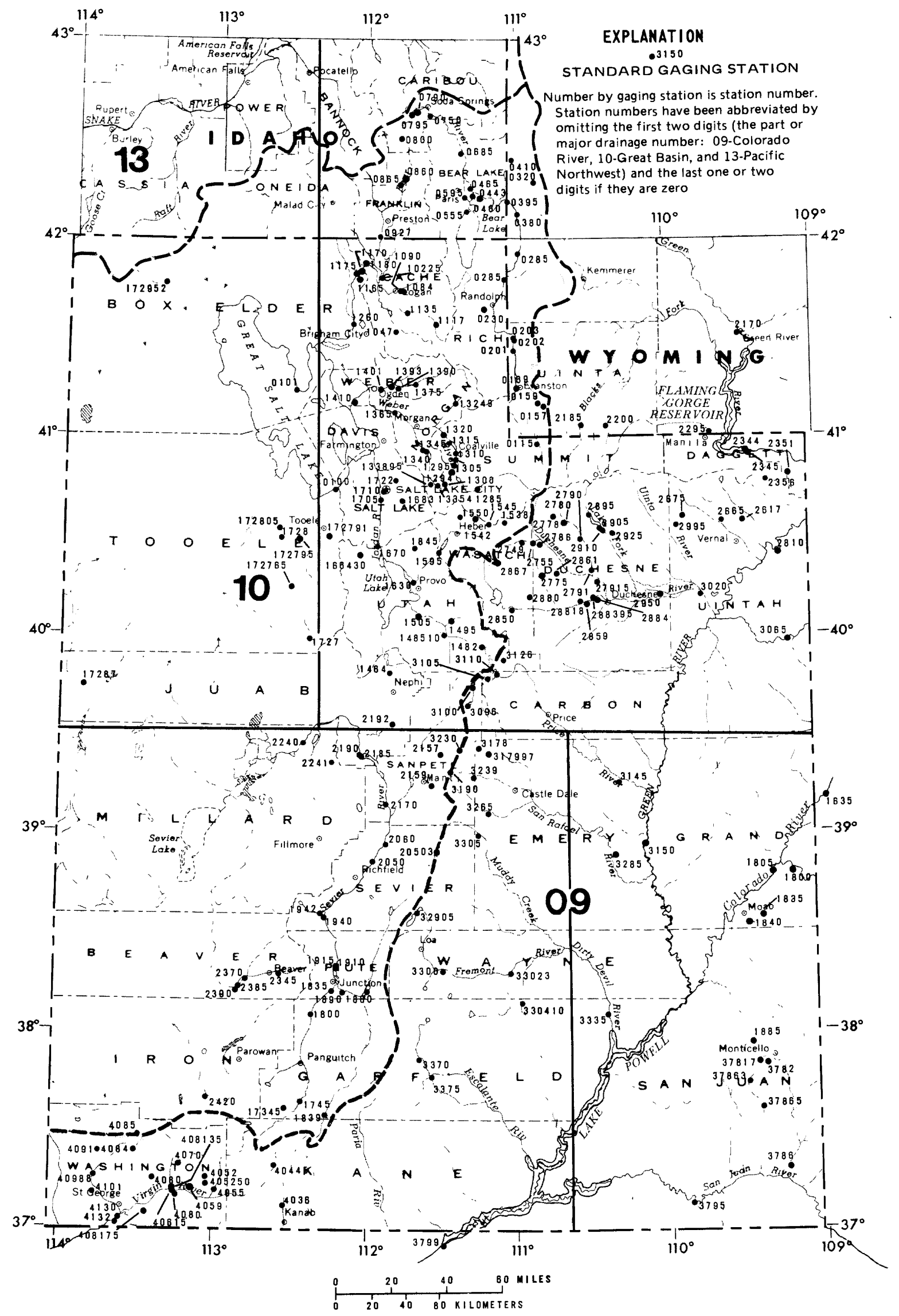

Figure 2.--Location of gaging stations. 


\section{Ground-water Data and \\ Ground-Water Conditions in Utah}

Number: UT-00-002

Cooperating Agencies: Utah Division of Water Rights; Utah Division of Water Resources; Utah Department of Transportation

Staff: L.R. Herbert, Hydrologic Technician, Project Chief and Editor of annual ground-water conditions report (part time)

Other District personnel as assigned

Period of Project: Continuing

Objectives: (1) To obtain long-term records of ground-water levels (fig. 3) for determination of water-level changes for yearly or other periods, (2) to determine withdrawals from aquifers and new wells drilled in the State, and (3) to make an annual evaluation of ground-water conditions in Utah and publish the information in a report.

Approach: Measure water levels annually or semiannually (normally February-March and September) and operate continuous water-level recorders on selected wells. Visit selected discharging irrigation wells, measure discharge, determine the ratio of water produced to energy consumed, and use the ratio along with energy-consumption data to compute total annual pumpage. Visit selected flowing wells and measure discharge. Obtain estimates of ground water withdrawn from wells for public supply and industrial use from the Utah Division of Water Rights. Obtain additional selected estimates of industrial use of water from wells by interviewing users, or by rating pumps and using the ratio of water produced to energy consumed with energy-consumption records. Determine the number and diameter of new wells drilled annually from well drillers' reports filed with the Division of Water Rights. Prepare an annual report on ground-water conditions in Utah which includes data, graphs, and maps showing water-level changes; withdrawals from wells; number of new wells drilled in defined ground-water basins or areas; changes in groundwater quality; and a discussion of ground-water conditions in each basin or area. Store water-level data in computer files and publish selected data in the annual report of water-resources data for Utah.

Progress: Water levels were measured in about 1,050 wells in February and March; in addition, water levels in about 630 of these wells were measured in September and water levels in 44 wells were measured monthly. Continuous water-level recorders were maintained on 29 wells. During the irrigation season, about 500 discharging irrigation wells were visited; discharge was measured at about one-half of the wells, and the ratio of water production to energy consumption was determined. Natural flow was measured for about 50 wells during the irrigation season. Number and diameters of wells drilled during the past year were determined. The twenty-seventh in the series of annual reports on ground-water conditions in Utah was completed. A draft of a report on how ground-water studies are done was prepared at the request of the Office of Water-Data Coordination, U.S. Geological Survey, and the report was revised following preliminary review. 
Plans for Next Year: Continue collecting, recording, and publishing data on water levels, groundwater withdrawals, and wells drilled. The twenty-eighth in the series of annual ground-water reports will be compiled. A draft of the report on how ground-water studies are done will be completed.

\section{Reports:}

Herbert, L.R., and others, 1990, Ground-water conditions in Utah, spring of 1990: Utah Division of Water Resources Cooperative Investigations Report 30.

ReMillard, M.D., and others, 1990, Water resources data for Utah, water year 1989: U.S Geological Survey Water-Data Report UT-89-1. 


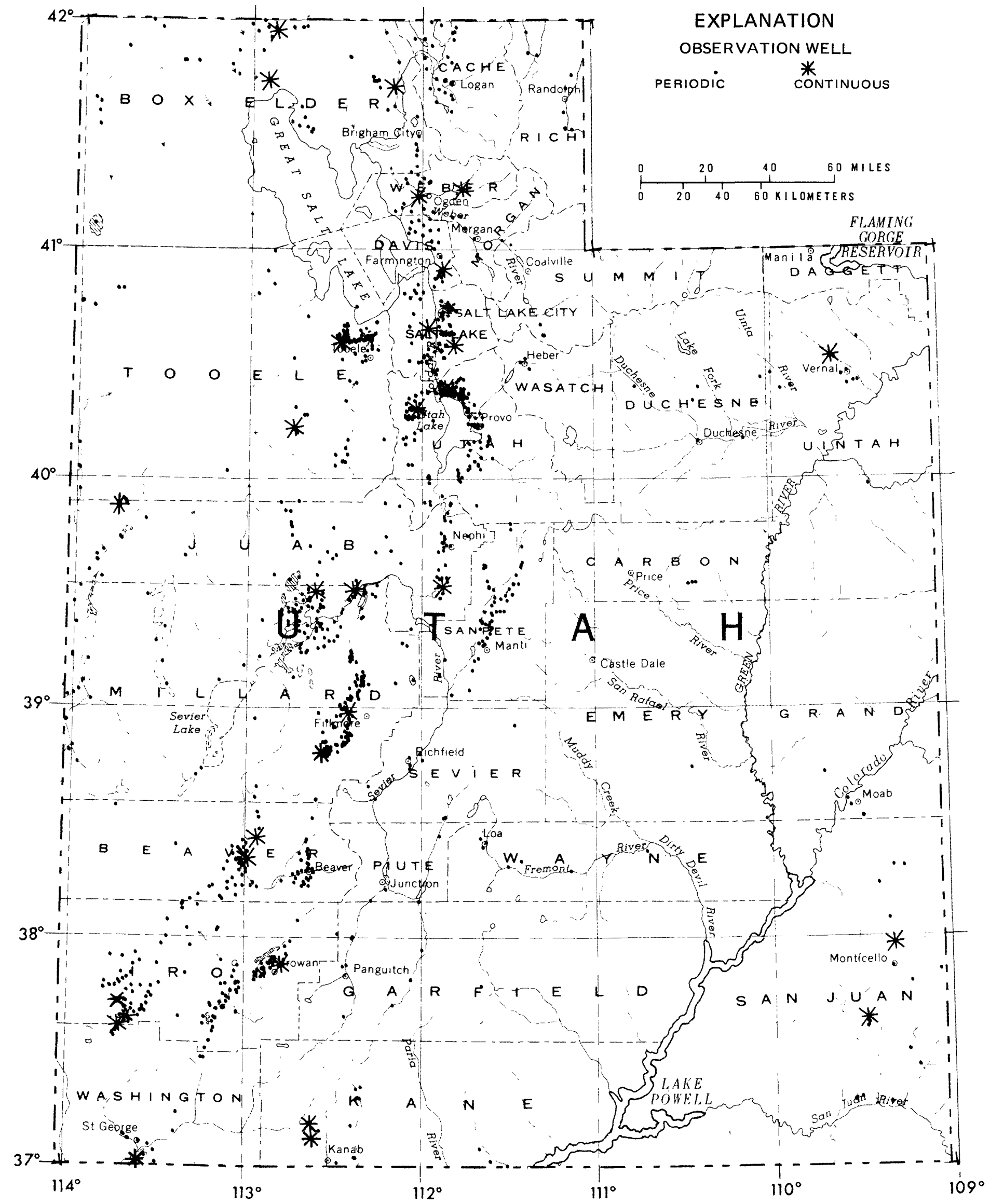

Figure 3.--Location of observation wells where ground-water levels were measured. 


\section{Water-Quality and Fluvial-Sediment Data}

Number: UT-00-003; UT-00-004

Cooperating Agencies: Utah Department of Agriculture; Utah Division of Water Resources; Utah Division of Water Rights; Utah Geological and Mineral Survey; U.S. Bureau of Land Management; U.S.Bureau of Reclamation; U.S. Soil Conservation Service

Staff: L.R. Herbert, Hydrologic Technician, Project Chief (part time); Other District personnel as assigned

\section{Period of Project: Continuing}

Objectives: To obtain records of the quality of water from streams (fig. 4) and wells (fig. 5), and records of sediment (fig. 4) at selected sites throughout Utah and at sites on Great Salt Lake.

Approach: Use standard methods for the collection and analysis of chemical-quality, fluvial-sediment, and biological samples, and computer storage and publication of data.

Progress: Samples for chemical analysis were obtained periodically (about 8 times per year) at 19 stream sites. In addition, temperature and specific-conductance data were obtained daily at five of these stream sites. Temperature and specific-conductance data also were obtained periodically at an additional 147 stream sites. Samples for chemical analysis of ground water were obtained from about 80 wells. In addition, field values for temperature and specific conductance were collected at about 75 wells. All water-quality data for streams and wells are listed in the annual water-resources data reports. Sixteen wells were sampled for pesticide contamination of ground water. Data collection on West Pond and drafts of three reports pertaining to the monitoring program and water and salt balance have been completed. Water quality in nine observation wells near the dikes of West Pond was monitored. The temperature and specific gravity at various depths for Great Salt Lake were monitored.

Physical and chemical data also were obtained for long-term sites on Great Salt Lake and West Pond of the West Desert pumping project. Temperature and density were measured at the sites at various depths, and selected samples were submitted for chemical and biological analyses. Seasonal and areal variations in water quality were defined by sampling about six times a year at eleven sites in the north part of Great Salt Lake. Sampling was done about six times a year at eleven sites in the south part of Great Salt Lake. Monthly measurements of temperature, density, and velocity of flow were made along several verticals through cross sections at both the upstream and downstream sides of the causeway at the breach between the south and north parts of the lake. Water quality was monitored in 17 observation wells near the dikes of the West Pond.

Sediment data were obtained daily at 5 sites and periodically at an additional 12 sites.

Two drainage basins were evaluated for nonpoint-source salinity in the upper Colorado River ba$\sin$.

Plans for Next Year: Continue collecting and processing data and preparing records for publication. Sample ground water from additional wells for pesticide contamination. Evaluate additional watersheds in the upper Colorado River basin using the Pacific Southwest Inter-Agency Committee (PSIAC) method for determining salinity loads entering the Colorado River. 


\section{Reports:}

ReMillard, M.D., and others, 1990, Water resources data for Utah, water year 1989: U.S. Geological Survey Water-Data Report UT-89-1. 


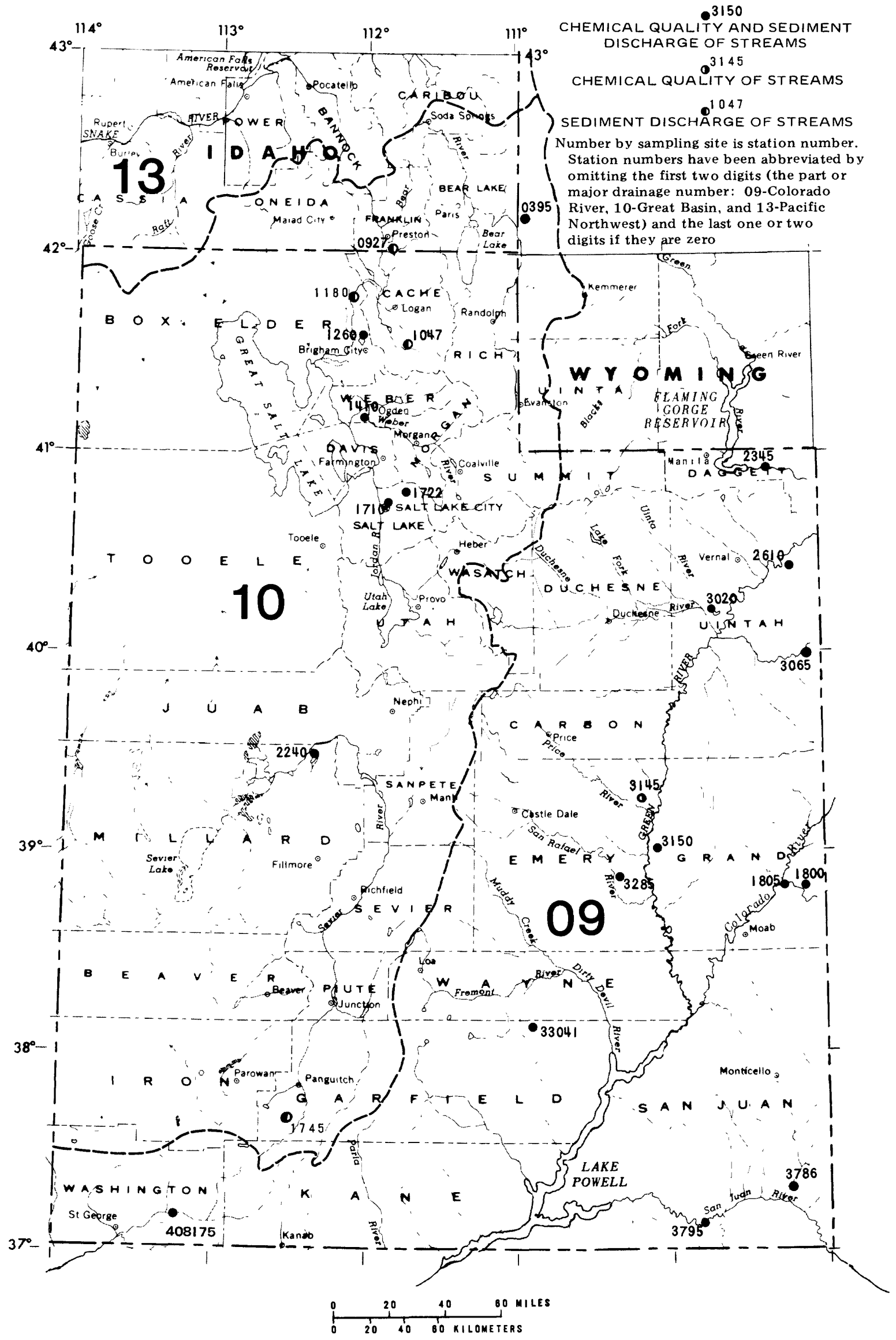

Figure 4.--Location of surface-water-quality stations. 


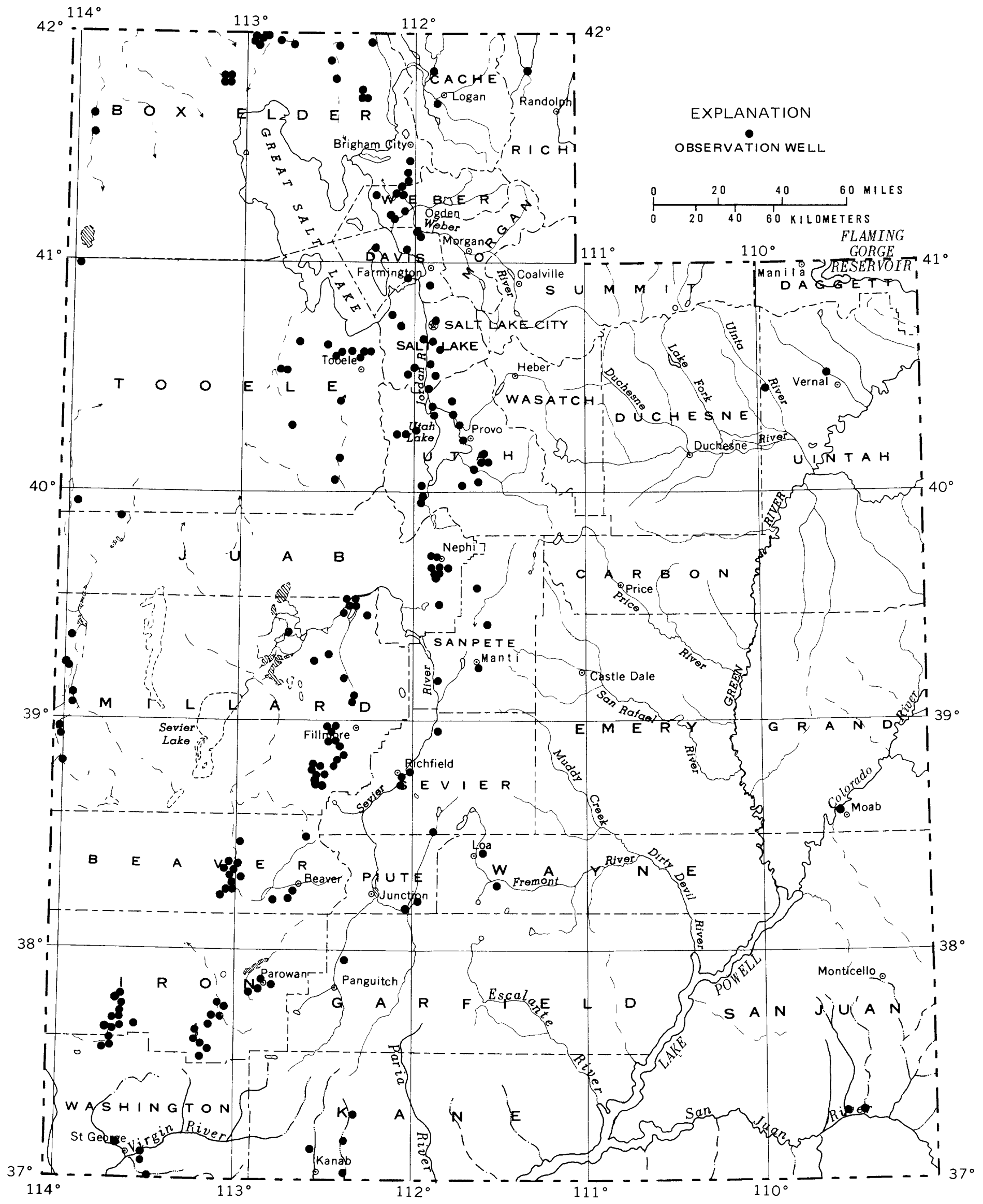

Figure 5.--Location of observation wells where water samples were collected for monitoring ground-water quality. 


\section{Interpretive Studies}

Locations of interpretive studies discussed in this section are shown in figure 6.

\section{Statewide Water Use}

Number: UT-00-007

Cooperating Agencies: Utah Division of Water Rights; Utah Division of Water Resources

Staff: G.E. Pyper, Hydrologist, Project Chief

H.K. Shlosar, Hydrologic Technician

Craig Morgan, Engineer, Utah Division of Water Rights

Other State and District personnel as assigned

Period of Project: Began July 1977, continuing

Objective: To obtain information about withdrawals and return flows of water for various uses, and consumptive use of water in connection with each type of withdrawal.

Approach: Determine total water diversions and consumptive use by verification of user measurements and records and, where possible, by field inventory and measurement of surface-water diversions and selected types of ground-water diversions. Use acreage and crop surveys to aid in estimating consumptive use by irrigation. State personnel are collecting data on public-supply and industrial use; U.S. Geological Survey personnel are collecting data on irrigation use.

Progress: Mail surveys were made by the Utah Division of Water Rights to determine water use by about 390 public water-suppliers and about 110 major self-supplied and public-supplied industries. No visits were made during the year to verify data from the public suppliers. Field verification of irrigated land during 1990 was made in hydrologic units 14070003, 14070006, 14070007, and 15010003 in south-central and southwestern Utah. Data on water use by agriculture (other than irrigation) and power generation were compiled for 1986, 1987, and 1988.

Plans for Next Year: Complete the collection, verification, and calculation of data for 13 wateruse categories for a 1990 National report by the U.S. Geological Survey. The Utah Division of Water Rights will contribute public-supply and industrial water-use data for this report. Continue the collection of irrigation water-use data in conjunction with the land-use surveys of the Utah Division of Water Resources in FY 1991, with focus on the Uinta Basin. 


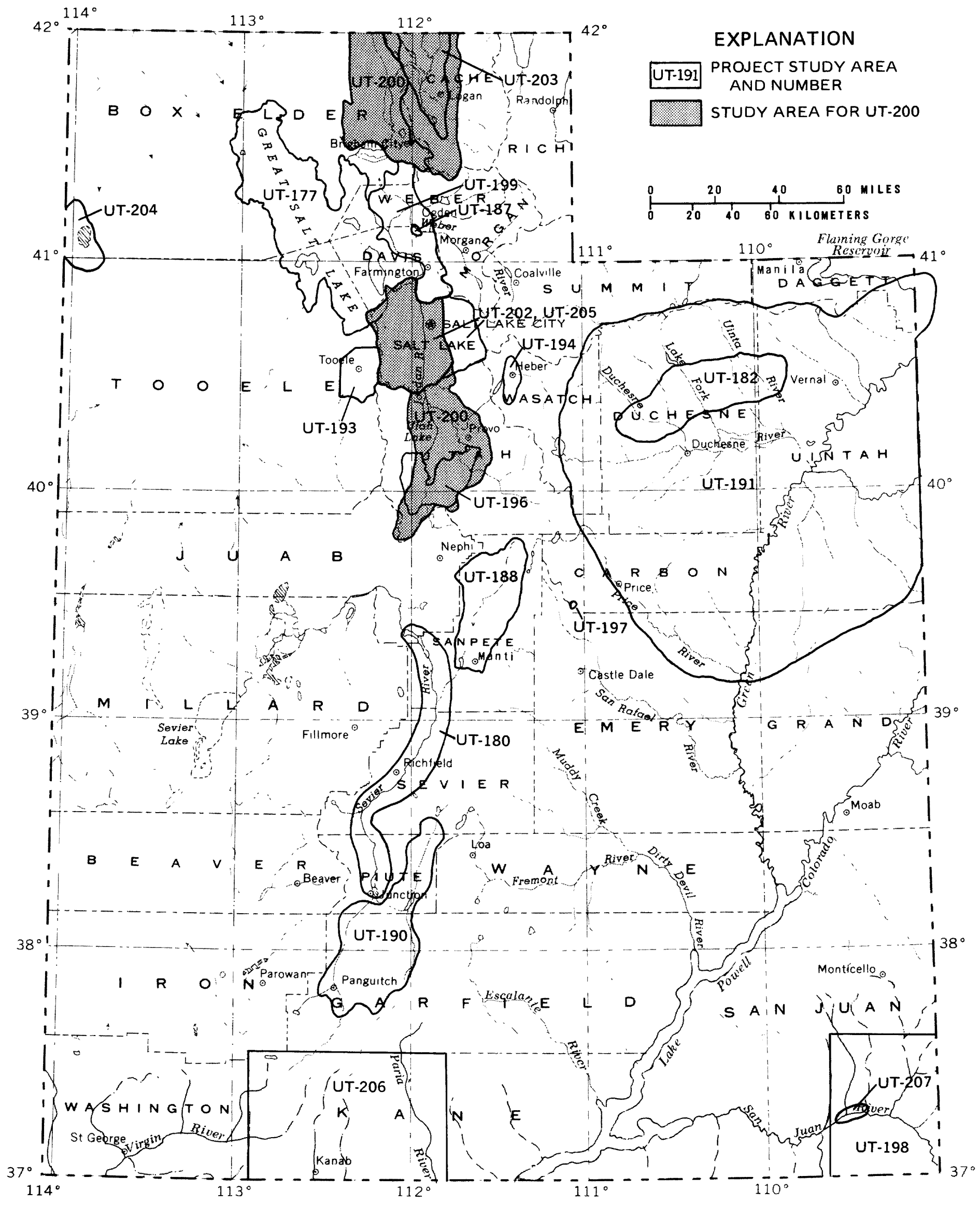

Figure 6.--Location of interpretive studies. 


\section{Model for Predicting the Water and Salt Balance \\ of Great Salt Lake for Selected Lake Levels}

Number: UT-87-177

Cooperating Agency: Utah Division of State Lands and Forestry

Staff: K.M. Waddell, Hydrologist, Project Chief (part time)

S.R. Wold, Hydrologist

Period of Project: January 1986 to December 1987

Objective: To update the existing model (constructed in 1972) of the water and salt balance for Great Salt Lake so that it can be used to predict the water and salt balance between the north and south parts of the lake for variable amounts of freshwater inflow. The existing model did not include higher water levels recorded during 1983 to 1987, or modification of the causeway between the north and south parts of the lake since 1972. Variations in stratification in the south part of the lake will be incorporated in the model, if possible.

Approach: Apply equations used for flow through the causeway breach from Holley and Waddell (1976), and develop new equations for stratified flows through the submerged culverts. Update the flow through the causeway fill, using the two-constituent solute-transport model of Sanford and Konikow (1985). Calibrate the fill-flow model by indirectly estimating flow through the causeway fill as the unknown variable, and calculating the fill-flow values using equations that describe the water and salt balance for the north and south parts of the lake. Determine the effects of different variables on stratification patterns by plotting time trends of density for each sampling section and then contrasting the trends for other parameters, such as surface inflow and breach width, that affect the water and salt balance of the lake.

Progress: Because of personnel constraints, little progress has been made on this study during FY 90.

Plans for Next Year: Complete calibration of overall model, determine effects of various parameters on stratification, and continue writing report. 


\section{Hydrology of the Central Sevier Valley, Central Utah, with Emphasis on the Sevier-Sigurd Basin}

Number: UT-86-180

Cooperating Agency: Utah Division of Water Rights

Staff: J.L. Mason, Project Chief

P.M. Lambert, Hydrologist

R.W. Puchta, Hydrologist

Period of Project: July 1986 to June 1990

Objectives: (1) To assess the current state of the hydrologic system of the central Sevier Valley in terms of surface-water flow, ground-water levels, and water quality; (2) to quantify the hydrologic system in terms of surface-water runoff and ground-water recharge, movement and discharge, and surface-water/ground-water relations; (3) to determine the factors that result in an increase in dissolved solids in surface and ground water along the valley; and (4) to estimate the effects of continued and increased ground-water withdrawals on the hydrologic system, including water quality.

Approach: Update data on streamflow, ground-water levels, and surface- and ground-water quality. Refine previous estimates of ground-water recharge and discharge, especially recharge from irrigation and discharge by seepage to the Sevier River. Sample ground and surface water to define in detail the changes that occur in water quality. Construct a digital model (or models) of the ground- and surface-water system (or a representative part of the system) of the central Sevier Valley to define surface-water/ground-water interaction. Install a series of shallow wells near selected river reaches to determine quality of ground-water seepage to the river and to obtain the gradient from the aquifer to the stream. Conduct seepage studies and sampling during low flow to better define quantity and quality of ground-water inflow to the river. Analyze ground water for isotopes to help determine sources of recharge, and to differentiate recharge by irrigation, precipitation, and inflow from adjacent areas. Apply geochemical models (such as salt-routing models) in an attempt to quantitatively characterize changes in water quality. A solute-transport model of a representative part or cross-section of the valley also may be used to study changes in ground-water quality. Use the analytical techniques to further estimate the effects of continued and increased ground-water withdrawals on the hydrologic system, including water quality.

Progress: Final computer simulations of the ground-water system in the Sevier-Sigurd basin were completed. All data collected during project were compiled for the final report. Water-quality and stable-isotope data were interpreted. The final report was completed and submitted for review.

Plans for Next Year: Process final report through review and publication. 


\section{Plan to Determine Effects of Injecting Brine, Uinta Basin}

Number: UT-87-182

Cooperating Agency: Utah Division of Oil, Gas, and Mining

Staff: G.W. Freethey, Hydrologist, Project Chief (part time)

Period of Project: October 1986 to September 1989

Objectives: To determine the best method of estimating the effects of subsurface injection of brines produced by oil and gas wells on the ground-water system in the Uinta Basin. If digital modeling is determined to be part of the method, define the types of data needed and the availability of those data for developing a model to simulate the hydraulic and chemical effects of injecting the brines. An objective added later was to characterize the geology and hydrology of the injection zone and overlying aquifer.

Approach: (1) Evaluate methods for estimating the effects of brine injection, especially the use of various digital models, (2) determine data requirements for modeling, (3) determine availability, sources, reliability, and distribution of these data, (4) design a data-collection program to obtain these data if they are not available, (5) begin model development if data are available and time allows, and (6) use geophysical and drillers' logs of oil-test and water wells to define and describe the injection zone and the overlying aquifers and their relations.

Progress: Geophysical logs for 72 oil-test wells in a part of the Altamont-Bluebell oil and gas field have been analyzed, and the geometry of the zone of salt-water injection has been defined. Maps showing the top, thickness, and depth below land surface of this zone have been prepared. The report discussing the geometry of this zone and the hydrology of the overlying aquifer is approximately 50 percent complete.

Plans for Next Year: An .Open-File map report of the study area in the Altamont-Bluebell field will be prepared. The maps will show structure contours of the top, thickness, and depth below land surface of the uppermost permeable injection zone. Geologic sections based on geophysical and stratigraphic logs will show lithologic and hydrologic characteristics above and for the zone, which is the shallowest zone of salt-water disposal. The sections will provide a third dimension to understanding these trends. 


\section{Ground-Water Contamination at Hill Air Force Base, Landfills 1 and 2}

Number: UT-88-187

Cooperating Agency: U.S. Air Force

Staff: K.M. Waddell, Hydrologist, Project Chief

L.J. Gerner, Hydrologist

C.B. Slaughter, Hydrologist (part time)

T.J. Burbey, Hydrologist, Nevada District (part time)

P.L. Haraden, Hydrologic Technician (part time)

Other District and Regional personnel as assigned

Period of Project: October 1987 to September 1992

Objectives: (1) To conduct a remedial investigation/feasibility study at landfills 1 and 2, Hill Air Force Base, to identify the existence of hazardous waste and to evaluate the source, extent, and degree of contamination of ground water; (2) to assess the risk to human health and the environment; and (3) to assess effects of alternative actions that will control or eliminate the risk.

Approach: Determine the hazard level of the site so that the proper safety equipment will be used. Define the source, extent, and degree of contamination by sampling and analyzing soil gas, by drilling and logging test holes and completing them as monitoring wells, by analyzing boreholegeophysical logs, and by sampling and analyzing cuttings and water. Conduct surface-geophysical surveys and use data from test holes to characterize the local hydrogeologic system. Measure water levels in monitoring wells to determine directions of ground-water movement. The data collected at the site will be used to prepare a risk assessment by a subcontractor.

Progress: Field-data collection and the draft of the remedial investigation report were completed. The report has been reviewed and corrections were incorporated. A ground-water-flow model was completed and particle-tracking simulations were done. The draft of the report for the model study has been completed.

Plans for Next Year: Complete reviews and revisions of remedial investigation and ground-watermodel reports. 


\section{Ground-Water Hydrology of Sanpete Valley}

and the San Pitch River Drainage Basin, Utah

Number: UT-88-188

Cooperating Agency: Utah Division of Water Rights

Staff: D.E. Wilberg, Hydrologist, Project Chief

V.M. Heilweil, Hydrologist (part time)

Period of Project: July 1987 to June 1990

Objectives: (1) To assess current hydrologic conditions in terms of ground-water occurrence, recharge, movement, and discharge; ground-water levels and quality; surface-water flow and quality; and ground- and surface-water interrelations; (2) to improve understanding of the hydrologic system and how it functions, especially the ground-water component; (3) to estimate the effects on the hydrologic system caused by potential redistribution or changes in the amounts and locations of ground-water withdrawals, importation of surface water, and modification of irrigation methods; (4) to determine causes for downstream deterioration in quality of surface water, the lesser deterioration in quality of ground water, and local variations in ground-water quality; (5) to define the relation between the consolidated-rock aquifer(s), the valley-fill aquifer, and surface water; (6) to locate the ground-water divide in the aquifer that underlies the San Pitch and Spanish Fork surface-water drainage basins; and (7) to assess basic ground-water conditions in the Indianola area.

Approach: (1) Compile data on ground water and surface water that have been collected since the last study in the area during 1964-67. (2) Measure or estimate ground-water discharge from wells and springs, to drains and streams, and by evapotranspiration; and estimate recharge from streams, irrigation, and seepage from consolidated rock. Conduct low-flow discharge measurements on the San Pitch River to delineate losing and gaining reaches and to estimate ground-water recharge and discharge, including irrigation return flow. Measure seepage losses on representative tributaries to determine the amount of runoff that contributes to ground-water recharge. (3) Measure water levels in wells to monitor spatial and temporal variations, to define directions of ground-water movement, and to determine ground-water divides. (4) Conduct aquifer tests to obtain hydraulic characteristics of the valley fill. (5) Construct a digital model of the valley-fill aquifer to simulate the three-dimensional ground-water system and to provide a means of estimating the effects of changes in the hydrologic system. (6) Install temporary surface-water gages on major tributaries of the San Pitch River in order to better define surface-water runoff prior to importation of surface water. (7) Sample and analyze water from wells, springs, streams, and drains to define variations in ground- and surface-water quality and to provide information to use in estimating causes of these variations. Sample selected ground- and surface-water sources from which samples have been collected previously for chemical analysis to determine if any water-quality deterioration has occurred; and correlate available analyses with geologic cross-sections and drillers' logs to determine possible causes of water-quality variation. (8) Compile drill-stem-test data from the few oil-test wells drilled in the area to help estimate the relations between the consolidated-rock aquifer and the valley-fill aquifer. 
Progress: The compilation of data for the study was completed, and a computer model for both steady-state and transient conditions was developed and calibrated. The model was used to simulate various stresses on the ground-water system. The text and illustrations for the final report were completed, and the report was submitted for review.

Plans for Next Year: Update and revise the report, incorporating the review comments, and submit the report for Regional review and Headquarters approval. 


\section{Ground-Water Hydrology of the \\ Upper Sevier River Basin, South-Central Utah, and Simulation of the Ground-Water System \\ in Panguitch Valley}

Number: UT-88-190

Cooperating Agency: Utah Division of Water Rights

Staff: S.A. Thiros, Hydrologist, Project Chief

W.C. Brothers, Hydrologist

Period of Project: July 1987 to June 1990

Objectives: (1) To define the hydrology of the upper Sevier River drainage basin and the current state of the hydrogeologic system, including the hydrologic budget and ground-water/surfacewater relations, and to improve the existing characterization of the ground-water system; (2) to define the chemical quality of ground and surface water and to describe the mechanisms for quality changes in the downstream direction; and (3) to estimate the hydrologic effects of increased ground-water development, changes in irrigation practices, and impoundment of surface water on ground-water levels, streamflow, spring discharge, and evapotranspiration.

Approach: (1) Compile all data on ground water, surface water, and chemical quality of water collected since the last study in the area in 1961-64. (2) Conduct seepage runs and/or install shortterm gaging stations along the major streams to define ground-water seepage to or from streams and gaining and losing reaches. Select observation wells where water levels can be measured to better define periods of ground-water seepage to or from streams. Conduct aquifer tests on suitable wells. (3) Estimate ground-water recharge from streams and irrigation, ground-water inflow from adjacent basins, and discharge by wells, springs, seepage to streams, and evapotranspiration. (4) Sample and analyze water from wells, springs, drains, and streams to define quality of ground and surface water, and use analyses to determine causes of downstream changes in water quality. (5) Construct analytical and/or digital models for simulating flow in parts of the basin to help estimate hydrologic effects of increased ground-water development, changes in irrigation practices, or surface-water impoundment.

Progress: A report on the ground-water hydrology of the area and simulation of the ground-water system in Panguitch Valley has been written and submitted for review.

Plans for Next Year: Revise report after review, submit for Regional review and Headquarters approval, and publish report. 


\section{Detailed Assessment of Effects of \\ Irrigation Drainage on Water Quality in the \\ Middle Green River Basin, Utah}

Number: UT-88-191

Cooperating Agency: Office of the Secretary, U.S. Department of the Interior

Staff: D.W. Stephens, Hydrologist, Project Chief

L.A. Peltz-Lewis, Hydrologic Technician

Period of Project: October 1988 to September 1991

Objectives: (1) To define the extent and severity of existing water-quality problems induced by irrigation drainage or the potential for future problems, and (2) to provide the scientific understanding needed for development of alternatives to mitigate or resolve identified problems. The areas that will receive detailed study are: Stewart Lake and associated Marsh 4720, lower Ashley Creek, and Ouray National Wildlife Refuge. Reconnaissance will be extended at Pariette Wetlands to include upstream agricultural areas in Pleasant Valley.

Approach: Determine the relative contribution of each of the drains to chemical loading by sampling drain water. Identify major contributing reaches, collect and analyze soil cores, and determine the potential for continued release of selenium if irrigation is continued, using sequential extractions. Analyze samples of shallow ground water collected from wells to determine selenium speciation in the drain water and compare to selenium speciation. Analyze samples of shallow ground water collected in the Jensen area by determining vertical and horizontal gradients, direction of flow, and concentration of dissolved constituents in the water at existing and new wells. Drill shallow wells north of Stewart Lake and case the wells to provide piezometers, which will be monitored periodically for water levels and sampled for chemical analysis to determine the concentration of selenium in the ground water.

Determine the degree to which the water has been concentrated by evaporation using hydrogen and oxygen isotopes as described by Deverel and Fujii (1988). Date the shallow ground water using tritium. Collect water samples at several locations for analysis of oxygen-18/oxygen-16 ratios, deuterium/ protium ratios, and tritium. Identify processes involved in precipitation of selenium, incorporation by sediments, and uptake by plants; and quantify by transect sampling and analysis of water, sediments, and plants.

Sample Ashley Creek from Vernal to its confluence with the Green River by synoptic methods. Collect samples from all inflowing water and from existing wells and analyze to determine quantities of selenium and total salts entering Ashley Creek.

Continue reconnaissance of water supplied to Marsh 4720 to determine if seasonal patterns exist in selenium content of the irrigation-drainage water. Determine the relation of water delivery in the Ruppe drain, Naples drain, and the oilfield canal to selenium entering the marsh.

Sample the outflow from Pelican Lake and Ouray Park Irrigation Company drainage, which provide inflow to the Ouray National Wildlife Refuge, at the refuge three times during the summer and analyze for selenium and major ions. Make a complete search of well records prior to test-well 
drilling to determine if existing wells could be used for monitoring. Sample by synoptic methods to identify stream reaches where the selenium input in ground water is greatest. Determine the distribution of selenium in the sediments in the Roadside Ponds and in Sheppard Pond S5.

Progress: Monitoring of water quality, flows, and water levels in wells has been completed at all sites. Water from shallow wells at Ouray contained as much as $9,300 \mu \mathrm{g} / \mathrm{L}$ selenium. Tributary inflows to Ashley Creek contained as much as $16,000 \mu \mathrm{g} / \mathrm{L}$ selenium. Shallow ground water leaches selenium from the surficial formations and is the source of the contamination. Deformed waterfowl have been found at Stewart Lake and Ouray. Several oral presentations have been made before technical and professional groups, two papers have been published in the proceedings of technical meetings, and two papers are in review. A data report has been completed and is in review. A draft of the final report is nearing completion.

Plans for Next Year: Complete the draft of the final report and submit it for review and approval. Obtain approval for the data report and publish it.

\section{Reports:}

Stephens, D.W., and Waddell, Bruce, 1989, Selenium contamination of water fowl areas in Utah and options for management: in Robarts, Richard, Proceedings of the Conference on Aquatic ecosystems in semi-arid regions, Saskatchewan, Canada, August 1990. 


\section{Hydrology and Water Availability in}

Southeastern Tooele Valley,

Northeastern Rush Valley, and Adjacent Areas in

the Oquirrh Mountains, Tooele County, Utah

Number: UT-88-193

Cooperating Agencies: Tooele County; City of Tooele

Staff: B.J. Stolp, Hydrologist, Project Chief

W. F. Holmes, Hydrologist (part time)

Period of Project: May 1988 to August 1990

Objectives: (1) To determine the saturated thickness and hydraulic characteristics of the basin fill in southeastern Tooele Valley; (2) to quantify the amount of water moving out of the Oquirrh Mountains via underflow in the channel alluvium of Soldier, Settlement, and Middle Canyons; (3) to determine the occurrence of ground water in and hydraulic properties of the consolidated rock of the Oquirrh Mountains; (4) to determine the average annual streamflow in Soldier, Settlement, and Middle Canyons.

Approach: Inventory and measure water levels of wells in southeastern Tooele Valley. Determine the depth to consolidated rock using drillers' logs and seismic surveys. Monitor water levels in and determine quality of water from selected wells. Perform aquifer tests to determine hydraulic parameters of the basin fill.

Obtain all water-level data, pumping records, and drillers' logs for municipal wells located at the mouths of Settlement and Middle Canyons, and continuously monitor water levels in selected wells. Inventory all wells and monitor water levels of selected wells at the mouth of Soldier Canyon. Perform aquifer tests on wells at canyon mouths to determine hydraulic properties of channel alluvium. If possible, conduct an aquifer test on two wells above the mouth of Middle Canyon. Collect water samples at selected sites for chemical analysis.

Determine the locations of all water sources (springs and tunnels) in the mountain areas, and monitor discharge at selected sites. Identify several candidate sites along the mountain front for possible test drilling into the consolidated rock. If test drilling is feasible and water is found in a test hole, conduct a slug or aquifer test to estimate hydraulic properties of the consolidated rock. Collect water samples from selected mountain sites for chemical analysis. On the basis of studies in adjacent areas, historical records, and streamflow monitoring during this study, estimate average annual streamflow for Soldier, Settlement, and Middle Canyons.

Progress: The spring inventory in the part of the study in the Oquirrh Mountains area was completed. Information concerning streamflow in Middle, Settlement, and Soldier Canyons was compiled from records of irrigation companies and other sources. Neutron, gamma, and fluid-resistivity logging was conducted on a well in the basin-fill deposits. Monthly monitoring of discharge of selected springs and water levels in wells continued through March 1990. Wells were inventoried on Kennecott Minerals Company property in the Pine Canyon area. A 96-hour aquifer test was 
conducted in December using wells located in the basin-fill deposits southwest of the City of Tooele. A draft of the final report was completed and submitted for review.

Plans for Next Year: The report will be revised following colleague review and submitted for Regional review and Headquarters approval. 


\section{Hydrology of Heber and Round Valleys, \\ Wasatch County, Utah, with Emphasis \\ on Ground Water}

Number: UT-88-194

Cooperating Agencies: Utah Division of Water Resources; Utah Division of Water Rights; Wasatch County; Central Utah Water Conservancy District; Wasatch County Water Users, Associated

Staff: W. F. Holmes, Hydrologist, Project Chief

D. M. Roark, Hydrologist

H. K. Shlosar, Hydrologic Technician (part time)

Period of Project: May 1988 to June 1990

Objectives: (1) To define and quantify recharge, movement, and discharge and improve definition of the ground-water systems of Heber and Round Valleys; (2) to define ground-water quality in the two valleys and its spatial and temporal variations; (3) to provide a method for assessing the effects on the hydrologic system of changes in surface-water flows, irrigation methods, and ground-water recharge in Heber Valley, and increased ground-water withdrawals in Round Valley; and (4) to discuss, in a written report, the hydrologic systems of Heber and Round Valleys and how the components of each system interact.

Approach: (1) Update the hydrologic data base. (2) Inventory all large-diameter wells drilled since 1968 and all wells in areas where data were lacking in the previous study, and drill observation wells where needed. (3) Assess the quality of ground water by collecting samples for laboratory analysis. (4) Conduct seepage studies, check diversion and streamflow records, and estimate recharge from irrigated fields and direct precipitation. (5) Estimate discharge from wells and springs and by evapotranspiration and seepage to Deer Creek Reservoir. (6) Compile water budgets for Heber and Round Valleys. (7) Construct a three-dimensional ground-water-flow model of Heber Valley to improve understanding of the hydrologic system and estimate water-level changes and changes in natural discharge related to potential changes in surface-water flows and irrigation practices.

Progress: Most domestic and large-diameter wells were inventoried. Monthly water-level measurements on 34 wells, which included 6 observation wells that were drilled and completed by the project, were done. Chemical analyses of water samples from about 35 springs and wells in both Heber and Round Valleys were done. All other field work was completed in August 1989, and all data collected were put in computer storage. The digital-computer model for Heber Valley was completed. The report was completed, reviewed, and approved.

Plans for Next Year: Publish the report.

\section{Reports:}

Roark, D.M., Holmes, W.F., and Shlosar, H.K., Hydrology of Heber and Round Valleys, Wasatch County, Utah, with emphasis on simulation of ground-water flow in Heber Valley, Utah Department of Natural Resources Technical Publication 101, (in press). 


\title{
Ground Water in Southern Utah
}

\author{
and Goshen Valleys, Utah County
}

Number: UT-88-196

Cooperating Agency: Utah Division of Water Rights

Staff: L.E. Brooks, Hydrologist, Project Chief

C.E. Hansen, Hydrologic Technician (part time)

Period of Project: October 1988 to September 1992

Objectives: (1) To assess current hydrologic conditions in terms of recharge, movement, and discharge of ground water, water levels, ground-water quality, and volumes of ground water in storage; (2) to better define the ground-water system and how its components interact; and (3) to estimate the effects of additional ground-water withdrawals on water levels, water quality, and surface water; and the effects of importation of additional surface water on the ground-water system.

Approach: (1) Compile existing data on wells, springs, water levels, ground-water quality, and surface-water flow. (2) Inventory ground-water discharge from wells and springs to drains and streams and by evapotranspiration and seepage to Utah Lake. (3) Estimate recharge, where feasible, from streams, irrigation, precipitation, and subsurface flow from consolidated rock. (4) Conduct aquifer tests to improve knowledge of hydraulic characteristics of the basin fill. (5) Construct a three-dimensional digital model of the ground-water system to simulate and better understand ground-water flow, and predict effects of proposed changes in water use on the system. (6) Prepare a basic-data report and an interpretive report of the study for publication by the Utah Department of Natural Resources.

Progress: Four aquifer tests were conducted, and several aquifer tests conducted during a previous study were reanalyzed using different methods. The specific capacities of wells were used to estimate transmissivity in areas where aquifer tests were not conducted. Analysis of drillers' logs indicated that continuous or well-defined confining and permeable layers do not exist; model layers will be determined on the basis of depth of perforations of wells that have known water levels or pumpage. The model grid was designed, but layers have not yet been defined. Discharge measurements were made at eight springs that were measured during the previous study to determine if changes in water use or climate had affected spring discharge. Channel-geometry measurements were made for a few perennial and intermittent streams to estimate the mean annual flow of ungaged streams; a percentage of the mean annual flow recharges the ground-water system as the streams enter the valley. Ground-water-quality patterns and changes were analyzed to select locations for ground-water sampling, and samples were collected from about 20 wells. Data on land use and surface-water diversions for irrigation were collected.

Plans for Next Year: Data from seepage measurements collected during the previous study along major rivers and canals will be analyzed; areas where existing data are incomplete will be defined. Stream-discharge measurements will be made in the major ground-water discharge areas to estimate discharge from springs, seeps, and drains tributary to the stream channels. Seepage measurements may be made in the areas not covered sufficiently during the previous study, or where changes in water use may have changed the amount of seepage. Consumptive use of water 
throughout the valleys will be estimated on the basis of land-use data. Consumptive use, precipitation, and surface-water-diversion data will be used, along with pumpage records, to determine evapotranspiration and recharge to the ground-water system. The model will be constructed, and the steady-state calibration completed. 


\section{Hydrologic Response to Land Subsidence \\ Caused by Underground Coal Mining, \\ Carbon County, Central Utah}

Number: UT-89-197

Cooperating Agency: Utah Division of Oil, Gas, and Mining

Staff: C.B. Slaughter, Hydrologist, Project Chief

G.W. Freethey, Hydrologist (part time)

Period of Project: October 1988 to September 1992

Objectives: (1) To determine the effect of longwall mining of coal on overlying ground water and surface water in an area where the thickness of overburden is less than 500 feet, and (2) to develop methods of determining the hydrologic effects of mining-related land subsidence.

Approach: (1) Install monitoring wells and collect and analyze data during the initial phase, the pre-mining period, and the removal of the Wattis coal seam in the Cyprus Plateau Mine; (2) monitor ground water during a less-intense second phase after removal of the Wattis seam; and (3) monitor ground-water and surface-water-data collection during a more intensive third phase as the Middle coal seam is being mined. Because of decreased funding, long-term monitoring to document the degree of recovery of the hydrologic system has been dropped from the project objectives.

Progress: In early June 1990, surface fractures were mapped and the North Fork of the Right Fork of Miller Creek was inspected after longwall mining of the Wattis seam was completed in April 1990. Two vertical, 2-inch exploratory holes drilled upward into the sandstone aquifer above the Middle seam in 1989 and in 1986 are draining water. Inflatable packers were installed below the sandstone aquifer in these holes, and battery-operated field-data recorders were installed to monitor water levels. In late August 1990, a third vertical, 2-inch exploratory hole was drilled upward from within the Cyprus Plateau Mine into the sandstone aquifer above the Middle seam, but the hole was dry.

A preliminary report outlining short-term effects of mining-induced subsidence on ground-water and surface-water systems is currently being written and is expected to be completed for technical review on or about November 1, 1990. This report will include data collected prior to and during mining of the Wattis seam through July 1990 and interpretations of these data.

Plans for Next Year: The third phase will be an intense monitoring and data-synthesis phase. The preliminary report will be updated with data on water levels and from chemical analyses of water samples from wells, springs, mine inflows, and the North Fork of the Right Fork of Miller Creek collected during the mining of the Middle seam. Monthly trips to the study area will be conducted to service equipment, collect water-level data and water samples from the monitoring welis, and monitor longwall mining of the Middle coal seam. 


\section{Investigation of Salinity of Water \\ in the Navajo-Sandstone Aquifer \\ in the Aneth Area, San Juan County, Utah}

Number: UT-89-198

Cooperating Agency: Utah Division of Oil, Gas, and Mining

Staff: L.E. Spangler, Hydrologist, Project Chief

Period of Project: October 1988 to September 1993, suspended in December 1989

Objectives: To determine (1) the extent of the area of saline water in the Navajo Sandstone; (2) the cause of the salinity; (3) the direction and rate of movement of the saline water; and (4) the character of the source of salinity (single point, multiple points, or a uniformly distributed source).

Approach: Considerably more geochemical, hydrochemical, geologic, and hydrologic information will be needed to determine the source of the saline water, its direction and rate of movement, and its areal extent. An investigation of the problem will be pursued in four phases: (1) Collect and compile new and existing geologic, geochemical, and hydrologic information, (2) collect and compile hydrochemical data, (3) analyze all data and develop a preliminary variable-density model to calculate possible flow directions for variably-saline fluids, and (4) develop and test final variabledensity-flow and solute-transport models.

Progress: During the first quarter of FY 90, nine additional wells were sampled, and the water was analyzed for common ions, trace elements, selected isotopes, and field parameters. After this initial data-collection effort, the project was suspended because of lack of funding, and additional work was limited to monitoring seven wells under a separate cooperative agreement with the Utah Divisin of Oil, Gas and Mining (included with UT-003) by sampling water and analyzing the samples to observe any changes in salinity that may have occurred since previous sampling. Water from 1 well in the Ismay field to the northeast of Aneth had an increase in dissolved-solids concentration from 6,740 to $11,900 \mathrm{mg} / \mathrm{L}$ from June 1989 to July 1990 .

Plans for Next Year: During the 1991 fiscal year, work on the salinity problems in the Aneth area will be limited to continued monitoring of the same seven wells under project UT-003, plus possibly several additional wells, to observe any changes in salinity that may have taken place. Samples will be collected and analyzed for the same constituents as in 1990. If additional funding is generated, the project will be activated, and a basic-data report will be prepared, summarizing all data and results obtained since the study began. 


\title{
Definition of Recharge Areas, Aquifers, and
}

\section{Confining Beds, and Classification of Aquifers}

\author{
Based on Water Quality in the East Shore Area \\ of Great Salt Lake; Box Elder, Weber, \\ and Davis Counties, Utah
}

Number: UT-88-199

Cooperating Agency: Utah Department of Health, Division of Environmental Health

Staff: K.R. Thompson, Hydrologist, Project Chief

P.B. Andersen, Consultant (part time)

S.R. Wold, Hydrologist

R.L. Baskin, Hydrologist (part time)

T.J. Dardon, Hydrologic Technician (part time)

Period of Project: October 1988 to December 1989

Objectives: (1) To define areas in which recharge to the principal water-yielding aquifers of the East Shore area occurs; (2) to define areas in which recharge could occur if land-use practices resulted in infiltration of water; (3) to define areas in which downward migration of water from the shallow unconfined aquifer potentially could occur if increased withdrawals of ground water from the confined principal aquifer resulted in a downward hydraulic gradient. These are areas in which the hydraulic gradient currently is upward and, thus, there currently is little potential for contamination; (4) to estimate ground-water velocities in recharge areas and define subareas where potential contamination could spread rapidly; (5) to compile available data on the thickness, lateral extent, and other relevant characteristics of aquifers and confining beds in the East Shore area; and (6) to improve knowledge of ground-water quality so the State of Utah can begin to define areas of the principal aquifers in terms of the State's aquifer-classification system, in which aquifers are classified on the basis of water quality.

Approach: (1) Compile all drillers', formation, and geophysical logs from likely recharge areas to identify where confining layers are absent (primary recharge area). (2) Use log and water-level data to identify areas where confining layers exist but the vertical hydraulic gradient is downward (secondary recharge area). (3) Compile information on horizontal hydraulic conductivity values used to construct the digital-computer models and values generated by calibration of models of the East Shore area. Use these data, as well as hydraulic gradients, to estimate areas of largest groundwater-flow velocities. (4) Use the digital-computer model to identify areas where withdrawals of water might cause a downward hydraulic gradient and result in the potential for movement of water from the shallow unconfined aquifer to the principal artesian aquifer. (5) Use geographic information system techniques to define areas of various aquifer and recharge-area characteristics and how they overlap, coincide, or relate to each other. (6) Select wells in various areas of the valley in order to obtain representative data from recharge areas near mountain fronts (both near and distant from losing reaches of streams); areas where confining beds exist but the vertical gradient is downward; areas where water is confined and the gradient is upward; and in areas of major groundwater discharge. Water from these wells will be sampled and analyzed for selected major constit- 
uents, trace metals, organic chemicals (including pesticides), and radionuclides. Most sampling sites will be wells in the principal artesian-aquifer system, as few wells are completed in the shallow unconfined aquifer. (7) Compile existing data on ground-water quality and prepare contour maps of dissolved solids in water of the principal artesian-aquifer system at concentrations of 500 , $1,000,3,000$, and $10,000 \mathrm{mg} / \mathrm{L}$. Identify areas where Utah's ground-water-quality standards are exceeded (data on trace metals, organic chemicals, and radionuclides are limited, so data may be mostly that collected for this project). (10) Prepare a report consisting of text and a series of maps portraying the recharge areas, direction of ground-water flow, extent of confining beds and aquifers, if possible, and water quality.

Progress: All field work has been completed. Base maps, maps of dissolved solids in ground water, maps of direction of ground-water flow, maps of potential reversals of vertical hydraulic gradient resulting from increased withdrawals, and preliminary recharge-area maps have been completed. All water-quality samples have been submitted to the laboratory and analytical results have been returned. The final report, which includes results of projects UT-199 and UT-200, is in technical review.

Plans for Next Year: Complete review process on the final report, submit it for Regional review and Headquarters approval, and publish the report. 


\section{Definition of Recharge Areas, Aquifers, and \\ Confining Beds, and Classification of Aquifers \\ in Terms of Water Quality - Wasatch Front, \\ Cache Valley, and Lower Bear River Valley \\ in Cache, Box Elder, Salt Lake, \\ and Utah Counties, Utah}

Number: UT-88-200

Cooperating Agency: Utah Department of Health, Division of Environmental Health

Staff: K.R. Thompson, Hydrologist, Project Chief

P.B. Andersen, Consultant (part time)

S.R. Wold, Hydrologist

R.L. Baskin, Hydrologist (part time)

T.J. Dardon, Hydrologic Technician (part time)

Period of Project: October 1988 to December 1989

Objectives: (1) To define recharge areas of the principal water-yielding aquifers in the basins along Wasatch Front, Cache Valley, and the lower Bear River Valley and provide supplemental data for existing studies of the recharge areas in Salt Lake Valley in cooperation with the Utah Division of Environmental Health and a study of ground water in southern Utah Valley in cooperation with the Utah Division of Water Rights; (2) to define areas in which recharge could occur if land-use practices resulted in infiltration of water; (3) to compile available data on the thickness, lateral extent, and other relevant characteristics of aquifers and confining beds in the basins along the Wasatch Front, Cache Valley, and the lower Bear River Valley; and (4) to improve knowledge of ground-water quality in these areas by sampling water from selected wells and springs for analysis of constituents listed in the State's ground-water quality standards. These data will enable the State to begin to define areas of the principal aquifers in terms of the State aquifer classification system, in which aquifers are classified on the basis of water quality.

Approach: (1) Compile all drillers', formation, and borehole-geophysical logs from likely recharge areas to identify where confining layers are absent (primary recharge area). (2) Use log and water-level data to identify areas where confining layers exist but the vertical hydraulic gradient is downward (secondary recharge area). (3) Select wells in various areas of each valley in order to obtain representative data from recharge areas near mountain fronts (both near and distant from losing reaches of streams); from areas where confining beds exist but the vertical gradient is downward; from areas where water is confined and the gradient is upward; and from areas of major ground-water discharge. These wells will be used for sampling and analysis of selected major constituents, trace metals, organic chemicals (including pesticides), and radionuclides. Most sampling sites will be wells in the principal artesian-aquifer system, as few wells are completed in the shallow unconfined aquifer. (4) Compile existing data on ground-water quality for each valley and prepare contour maps of dissolved solids in water for the principal artesian-aquifer system at concentrations of $500,1,000,3,000$, and $10,000 \mathrm{mg} / \mathrm{L}$. Identify areas where Utah's ground-water-quality standards are exceeded (data on trace metals, organic chemicals, and radionuclides are limited, so 
data may be largely that collected for this project). (5) Prepare a report that will consist of text and a series of maps, showing the recharge areas, direction of ground-water flow, the extent of the aquifer(s) and confining bed(s), if possible, and water quality in all areas.

Progress: All field work has been completed. Base maps, maps of dissolved solids in ground water, maps of direction of ground-water flow, and preliminary recharge-area maps are nearing completion. All water-quality samples have been forwarded to the laboratory and analytical results have been returned. The final report, which includes results of projects UT-199 and UT-200, is in technical review.

Plans for Next Year: Complete review process on the final report, submit it for Regional review and Headquarters approval, and publish the report. 


\section{Innovative Techniques of Mapping Attributes \\ in Support of Wellhead Protection Area \\ Delineation, Salt Lake County, Utah}

Number: UT-90-202

Cooperating Agency: U.S. Environmental Protection Agency

Staff: G.W. Freethey, Hydrologist, Project Chief (part time)

L.E. Spangler, Hydrologist (part time)

Period of Project: October 1989 to March 1991

Objectives: (1) To map the areal distribution of hydraulic conductivity using existing hydrogeologic data from reports, well logs, aquifer tests, and geophysical logs; (2) to measure water levels and develop up-to-date contour maps of the potentiometric surface for the principal aquifer; (3) to assign values of effective porosity to the principal aquifer based on lithologic character and probable depositional environment; (4) to develop an areal distribution of average linear velocity of ground water in the principal aquifer based on distribution maps developed for the first three objectives; and (5) to demonstrate how time-of-travel along flow paths to wells can be estimated from the distribution map of average linear velocity.

Approach: The steps involved will be as follows: (1) Choose an appropriate study area along the Wasatch Front that includes a typical number of public-supply wells. (2) Compile data from drillers' logs, aquifer tests, and geophysical logs, and water-level information for the area. (3) Extract pertinent information from these sources to derive values for hydraulic conductivity, effective porosity, and head gradients. (4) Develop potentiometric-surface maps and hydraulic-head distributions for the high and low water-level periods of 1990. (5) Develop average linear velocity distribution for these two periods from the areal distributions of hydraulic conductivity, effective porosity, and head gradients. (6) Determine time-of-travel along selected flow lines, mark points of predetermined transit times (250-day, 15-year, etc.), and show how lines connecting these points could define various protection areas as defined by the State of Utah Wellhead Protection guidelines.

Progress: Water levels were measured in February and August 1990 and potentiometric-surface maps prepared. A map of estimated porosity distribution was developed from a geologic map and extrapolation of knowledge about depositional environments of the material present. Hydraulicgradient distributions were developed for February and August 1990.

Plans for Next Year: Definition of distribution of hydraulic conductivity for the principal aquifer will be completed and a report written. Scheduled completion for a draft of the report is March 1991. The report will be submitted for review and revised prior to submittal for Regional review and Headquarters approval. 


\section{Ground Water and Ground-Water/Surface-Water Relations \\ in Cache Valley, Cache County, Utah, and Adjacent Parts of Idaho}

Number: UT-89-203

Cooperating Agencies: Utah Division of Water Resources and Utah Division of Water Rights

Staff: K.A. Kariya, Hydrologist, Project Chief

D.M. Roark, Hydrologist

F.R. Hayes, Hydrologic Technician

Period of Project: September 1989 to September 1992

Objectives: (1) To assess current ground-water conditions, especially in terms of water levels, well and spring discharge, ground-water quality, and volumes of water in storage, and to document changes in conditions since the last study in 1967-69; (2) to better define the components of the ground-water system in terms of recharge, movement, and discharge, with emphasis on groundwater/surface-water relations; and (3) to determine how the components of the system interact, and to estimate the effects of additional ground-water withdrawals in varius locations on water levels, streamflow, spring discharge, and evapotranspiration.

Approach: Compile available data on wells, springs, water levels, ground-water quality, and streamflow, focusing on post-1969 data, and collect data on wells drilled since the last study in 1967-69. Measure or estimate ground-water discharge by wells and springs, to drains and streams, and by evapotranspiration. Estimate recharge from streams; irrigation, including that from canals; precipitation; and subsurface flow from consolidated rock. Conduct seepage runs on streams, if possible, to define ground-water/surface-water relations and estimate recharge from and discharge to streams. Prepare a map of the potentiometric surface, and, if possible, prepare maps showing aquifer thickness and distribution of water quality. Conduct aquifer tests to improve knowledge of hydraulic characteristics of the basin fill. Construct a three-dimensional digital model of the ground-water system to help understand how the components of the system interact and how increased development of ground water in various parts of the valley would affect water levels, spring discharge, streamflow, and evapotranspiration. Prepare a basic-data report and an interpretive report for publication by the Utah Department of Natural Resources.

Progress: A work plan was completed. Existing data have been compiled for wells, springs, water levels, ground-water quality, and streamflow. An observation-well network has been established and wells are monitored monthly. Seepage studies were made on select reaches of a few canals. Project personnel designed a seepage study of the Bear River, which will be done by the Hydrologic Surveillance Section of the Utah District under project U'T-001. Pumps on irrigation wells were rated. Discharge was measured in all large-discharge springs. Channel geometry measurements were completed on ephemeral streams. A continuous water-level recorder was installed in a well at Logan, Utah. 
Plans for Next Year: Continue design and production of the base map. Conduct seepage runs on major streams. Install a small number of shallow observation wells. Conduct aquifer tests. Remeasure discharge of major springs. Measure water levels in an extensive number of wells and use data to construct a potentiometric-surface map. Rate pumps in additional irrigation wells. Design, construct, and calibrate surface-water/ground-water digital model. Prepare basic-data report. 


\title{
Identification and Quantification of Mechanisms
}

\author{
Causing Decreasing Salt-Crust Thickness, \\ Bonneville Salt Flats, Western Utah
}

Number: UT-90-204

Cooperating Agency: U.S. Bureau of Land Management

Staff: J.L. Mason, Hydrologist, Project Chief

W.C. Brothers, Hydrologist

R.L. Baskin, Hydrologist (part time)

Hydrologist, Vacant, National Research Program, Denver, Colorado (part time)

\section{Period of Project: January 1990 to December 1992}

Objectives: (1) To document changes in the hydrologic system since the study by Lines (1979); (2) to establish a data-collection network to monitor future changes in water levels, water chemistry, and salt thickness in the Bonneville Salt Flats; (3) to assess the potential for removal of salts from the salt flats area via wind-driven ponds; and (4) to assess the impacts of current and projected brine withdrawals, other man-induced variations, and climatic changes on the hydrologic system. This includes impacts on ground-water chemistry, water levels, and salt deposits in the Bonneville Salt Flats.

Approach: (1) Prepare a detailed plan of study and review entire plan with the U.S. Bureau of Land Management (USBLM) and other entities selected by USBLM. (2) Define formation and movement of ponds using LANDSAT and other available aerial photography of the salt-flats area. (3) Develop preliminary three-dimensional solute-transport model. (4) Gather data collected or available since Lines (1979) conducted his study, including brine-withdrawal, water-level, chemical-analysis, meteorological, soil-moisture, and other pertinent data for the past 12 years. (5) Locate observation wells drilled during and prior to Lines' study. (6) Establish observation-well network for monthly water levels and collection of samples of brine for density analysis. (7) Drill new observation wells on and adjacent to the salt flats. Cores will be collected and analyzed for mineralogical content. Salt thickness and water levels will be measured, samples of brine will be collected and analyzed, and the wells will be added to the observation-well network. Nested wells (or adjacent wells completed at different depths) will be part of the drilling plan in order to determine vertical variation in water levels, water density, and chemistry. One or more production wells (8 inches or larger) and several observation wells near each production well will be drilled for use in an aquifer test or tests. (8) Conduct and analyze aquifer tests on wells and ditches. (9) Assess raceway surface/salt to attempt to describe the technical (physical, geologic, hydrologic, geomorphic, sediment) factors contributing to an acceptable raceway surface. At least five soil-moisture holes will be drilled, and properly completed, and instrumented to collect data on temporal variations. (10) Conduct geochemical studies to estimate the geochemical flow paths and reactions along these paths and to describe processes that may increase or decrease the salt thickness and area. (11) Design and construct a transport model to simulate the flow rates, flow paths, and chemical concentrations and migration of selected constituents. The model will be used to simulate future water levels and ground-water chemistry using alternative scenarios supplied by Reilly Industries and USBLM. (12) Prepare reports documenting the results of the study. 
Progress: The project proposal was revised several times as the scope of the project was changed through suggestions made by the USBLM Technical Review Committee. Initial conceptual transport modeling was begun by the solute-transport research group in Denver. The location and condition of 55 wells constructed during the previous study in the Bonneville Salt Flats area were verified. Construction of 14 observation wells in the shallow-brine aquifer was completed.

Plans for Next Year: Prepare project planning document. Locate remaining monitoring wells and drill additional wells in the shallow-brine aquifer. Continue to develop preliminary solute-transport models. Measure water levels in observation-well network and collect samples for brinechemistry analysis. If necessary, instrument brine-collection ditch to determine annual withdrawal. If funding is available, contract installation of three weather stations, drill deep observation wells in alluvial-fan and basin-fill aquifers, begin aerial photography, collect data on the ground for analysis of salt transport by wind-driven ponds, and drill observation wells and begin monitoring in Pilot Valley. 


\section{Ground-Water Flow and Solute Migration \\ in the Salt Lake Valley, Utah}

Number: UT-90-205

Cooperating Agencies: Utah Division of Water Rights, Utah Division of Environmental Health, and local municipalities and water agencies

Staff: G.W. Freethey and W.F. Holmes, Project Supervisors, (part time)

S.A. Thiros, Hydrologist

P.M. Lambert, Hydrologist (part time)

D.J. Ballard, Hydrologic Technician (part time)

Period of Project: March 1990 through September 1994

Objectives: (1) To better define the quality of water in the shallow unconfined aquifer and the confining unit in Salt Lake Valley; (2) to determine the hydrologic properties of the shallow unconfined aquifer and the underlying confining unit; (3) to better define the ground-water/hydrochemical flow system, including three-dimensional variation of hydrologic properties and ground-water quality; and (4) to provide the Utah Divisions of Water Rights and Environmental Health with a means of determining the quantity of water that can be withdrawn from different areas in the Salt Lake Valley without causing undesirable water-level declines and without inducing water with large concentrations of dissolved solids or contaminants to migrate toward wells used for municipal and industrial water supply.

Approach: The approach to achieving the objectives will involve several components of field investigation and information interpretation. The following components are integrated and each is necessary for accomplishing the objectives stated: (1) Determine aquifer and confining-unit properties, and chemical composition of the water by drilling, field testing of water-level response to withdrawals from wells, and laboratory testing of cores and water samples; (2) determine the extent of the effects of variable-density fluid movement; (3) update and refine the existing groundwater flow model; (4) conduct a particle-tracking simulation using the model to increase knowledge about source and movement of water of various degrees of salinity in specific parts of the system; (5) develop multiple solute-transport simulations to better understand the hydrochemical system in the valley; and (6) synthesize collected information and write the reports.

Progress: Existing information on the shallow unconfined aquifer was collected from the files of the Utah Division of Environmental Health. Information on public-supply wells and on the principal aquifer also was compiled and plotted on a map of the Salt Lake Valley. Areas where data were lacking were defined as potential locations for drilling monitoring wells. In June and July, 27 wells were drilled to help define and monitor the shallow unconfined aquifer and the underlying confining unit. Cores collected from 16 of these wells were analyzed for a variety of properties.

The relative importance of density-related gravity effects on ground-water flow is being examined. The horizontal and vertical fluid-density distribution in the ground-water system was estimated on the basis of available water-quality data. Output from the existing ground-water flow model was used to define horizontal and vertical hydraulic gradients. Areas where the effects of variable-density fluid movement may be substantial were determined by comparing the hydraulic pressure- 
driven component of flow with a representation of the density-related gravity-driven component of flow at selected sites in the valley.

Work was begun on updating and refining the existing ground-water-flow model. Available contoured data defining subsurface lithology in the area have been digitized.

Plans for Next Year: Collect and chemically analyze samples of water from recently drilled monitoring wells in October and November 1990. Drill and complete an additional 16 monitoring wells in the shallow unconfined aquifer and confining unit. Obtain water samples from wells and analyze for major inorganic ions and selected metals and organic chemicals. Conduct slug tests and aquifer tests on monitoring wells. Begin variable- and constant-density modeling. Continue updating and recalibrating the existing flow model as new data become available. Begin development of variable-density and solute-transport models. 


\section{Definition of Recharge Areas, Physical Extent, and \\ Quality in the Principal Aquifers \\ in Western Kane County, Utah}

Number: UT-90-206

Cooperating Agencies: Utah Division of Environmental Health, Kane County, the City of Kanab, and the Kanab Area Water Association, Inc., through the Five County Association of Governments.

Staff: L.E. Spangler, Hydrologist, Project Chief (part time)

Period of Project: March 1990 through February 1991

Objectives: (1) To define and describe the physical boundaries of the principal aquifers in western Kane County, including the variability in thickness and the upper, lower, and lateral extents; (2) to identify the recharge areas for the aquifers and the relative quantity of recharge provided by each of these areas; and (3) to provide the maps necessary for preliminary classification of the ground water in these aquifers using the State's aquifer-classification system which is based on chemical quality of water.

Approach: Because of limited funding, field work will be restricted to collection of six to eight water samples. Remaining information necessary to complete the project will be obtained from available reports and data in the files of the U.S. Geological Survey and State agencies. The basic approach will be as follows: (1) Compile and review geologic reports to identify lateral and vertical extent and lithologic character of formations. This will lead to a preliminary categorization of aquifers and confining layers within 2,000 feet of land surface. (2) Compile drillers' and geophysical logs and water-quality information from the files of the U.S. Geological Survey, the Utah Division of Water Rights, and Petroleum Information, Inc., to identify aquifers and their dimensions and to initially determine depth to water and relative quality of ground water. (3) Use information from existing digital models and from available aquifer tests, specific-capacity tests, water-level measurements, and drill-stem tests to compile hydrologic data needed to estimate ground-waterflow-velocity values between recharge and discharge areas. (4) Use geographic information system techniques to portray and characterize aquifers, confining layers, and recharge areas, and to determine how they spatially relate to each other. (5) Prepare maps showing: (a) Lateral extent of principal aquifers that occur within 2,000 feet of land surface, (b) thickness of principal aquifers, (c) location of recharge areas for the principal aquifers, and (d) summary of chemical quality of water in the principal aquifers from previously collected water-quality data. (6) Select and sample six to eight wells tapping the area's primary aquifer (the Navajo Sandstone) and analyze for major chemical constituents, trace metals, organic chemicals, and radionuclides. These will serve as baseline data for comparison with future samples collected during further development of water from the Navajo aquifer.

Progress: During the 1990 fiscal year, five water samples were collected from wells and springs discharging from the Navajo aquifer and analyzed for common ions, trace metals, organic compounds, and gross alpha/beta activity. Temperature, specific conductance, $\mathrm{pH}$, and alkalinity were measured in the field for all samples. Since collection, analyses for most of the samples have been 
completed and results compiled. Several maps have been prepared for the study area in addition to the base map. These include maps showing the outcrop areas for the Navajo Sandstone and surrounding geologic units, the areal extent and thickness of the aquifers, areas of potential recharge to the Navajo Sandstone, including overlying valley-fill deposits, and areal variation in dissolved solids in ground water in the aquifers. Compilation of U.S. Geological Survey and Utah Division of Environmental Health water-quality data indicates that ground water in these aquifers can be defined as class 1A, "pristine ground water", and class 1B, "irreplaceable ground water", under Division of Environmental Health standards.

Plans for Next Year: Three additional water samples will be collected by the U.S. Geological Survey and analyzed by the Utah Division of Environmental Health during the first quarter of this fiscal year. Results from these analyses will be integrated with other data to complete the maps necessary for preliminary classification of ground water in this area. Report writing has begun and a preliminary draft is scheduled to be completed by January $31,1991$. 


\title{
Determination of Channel-Migration Processes,
}

\author{
San Juan River Near Bluff, Utah
}

Number: UT-90-207

Cooperating Agency: U.S. Bureau of Indian Affairs

Staff: H.L. Case, Hydrologist, Project Chief

R.L. Baskin, Hydrologist (part time)

Other District personnel as assigned

Period of Project: July 1990 through January 1991

Objective: To determine the change in course of the San Juan River near Bluff, Utah, from 1899 to the present and to define the historical channel-migration process. The first phase of the study will provide information to assist the U.S. Bureau of Indian Affairs (USBIA) in determining if additional work to document historic flows and channel changes is practical and warranted.

Approach: (1) Search for and document all available records of historical hydrologic events in the area related to potential shifts in channel location of the San Juan River (Phase I). (2) Determine areal extent of present and past channels, map geographic features, and conduct geologic mapping and sampling necessary to substantiate amount, direction, and type of channel migration (Phase II). (3) Determine effects of riprapping and other man-made structures as well as the effect of major floods on the position of the channel. (4) Prepare a report describing movement of the channel of the San Juan River near Bluff, Utah, and its cause (accretion or avulsion) during the approximate period 1899 to the present. The report will include analysis of all available evidence, including data on sedimentation, to establish the cause of changes in the location of the river.

Progress: A detailed workplan was developed and a field reconnaissance was done. Five locations for detailed topographic cross sections from the San Juan River to the edge of the floodplain in the Bluff area were selected, and the sections were measured. The Agricultural Stabilization and Conservation Service, National Archives, and Library of Congress in Washington, D.C., and U.S. Bureau of Land Management (USBLM) offices in Moab and Monticello, Utah, were contacted to obtain aerial photographs and other information. Digitizing of the location of the San Juan River at different historic times was begun using photographs. Historic hydrologic records for the San Juan River were reviewed, and a table showing historic peak discharges was developed.

Literature searches at the University of Utah Library, the Utah Historical Society, Salt Lake Library, newspapers, and the Church of Jesus Christ of Latter Day Saints historical archives were done. Copies were obtained of pertinent photographs and articles that documented the position of the San Juan River and/or discussed man's activities related to the river near Bluff, Utah. Preliminary results of the study were discussed in a meeting with the BIA and BLM personnel in late September.

Plans for Next Year: Complete digitizing location, at selected points in time, of the San Juan River near Bluff. Review records in BIA files. Complete search for pertinent articles in newspaper and agency files. Prepare a draft report describing the results of the investigation and submit the report for technical review. 


\section{REFERENCES CITED}

Deverel, S.J., and Fujii, R., 1988, Processes affecting the distribution of selenium in shallow ground water of agricultural areas, San Joaquin Valley, California: Water Resources Research 24 , no. 4, p. 516-524.

Holley, E.R., and Waddell, K.M., 1976, Stratified flow in Great Salt Lake culvert: Journal of the Hydraulics Division, American Society of Civil Engineers, v. 102, no. HY7, Proceedings Paper 12250, July 1976, p. 969-985.

Lines, G.C., 1979, Hydrology and surface morphology of the Bonneville Salt Flats and Pilot Valley Playa, Utah: U.S. Geological Survey Water Supply Paper 2057, 107 p.

Pacific Southwest Inter-Agency Committee, 1968, Factors affecting sediment yield and measures for the reduction of erosion and sediment yield, $28 \mathrm{p}$.

Sanford, W.E., and Konikow, L.F., 1985, A two-constituent solute-transport model for ground water having variable density: U.S. Geological Survey Water-Resources Investigations Report 85-4279, 88 p. 